\title{
ARCABOUÇO TECTÔNICO E ESTRATIGRÁFICO DA FAIXA RIACHO DO PONTAL, DIVISA PERNAMBUCO-PIAUI-BAHIA
}

\author{
Fabrício de Andrade Caxito ${ }^{1} \&$ Alexandre Uhlein ${ }^{1}$ \\ 1 - Departamento de Geologia, Instituto de Geociências, Universidade Federal de Minas Gerais, Av. Antônio Carlos 6627, CEP 31270-901, Belo \\ Horizonte, MG, Brasil.facaxito@yahoo.com.br; auhlein@gmail.com
}

Recebido em 18 de setembro de 2013; aceito em 25 de outubro de 2013

RESUMO: A faixa brasiliana Riacho do Pontal bordeja a margem norte do Cráton do São Francisco e pode ser subdividida em três domínios ou zonas tectônicas de características geológicas contrastantes, de norte para sul: zonas Interna, Central, e Externa. A Zona Interna é dominada por rochas metavulcanosedimentares intrudidas por rochas plutônicas relacionadas à Orogênese Cariris Velhos (augen-gnaisses da Suíte Afeição, 1.0-0.9 Ga). A Zona Central é caracterizada pelo Complexo Monte Orebe, composto por metabasaltos de geoquímica similar aos basaltos de cadeia oceânica e rochas metassedimentares de ambiente marinho profundo. A Zona Externa é caracterizada pelo sistema de nappes Casa Nova, composto por duas unidades: A Formação Barra Bonita na base, que representa uma sequência plataformal desenvolvida na borda norte do paleocontinente São Francisco; e a Formação Mandacaru no topo, que representa uma sequência marinha profunda turbidítica, provavelmente sin-orogênica. Essas rochas foram afetadas por deformação compressiva (D1-D2-D3) com o desenvolvimento do sistema de nappes vergentes para sul, durante o Neoproterozoico ( 630-575 Ma), seguida por deformação transcorrente (D4) nos estágios tardios da Orogênese Brasiliana. Toda a faixa é intrudida por múltiplas gerações de plútons graníticos e sieníticos sin a pós-colisionais, de idade neoproterozóica a cambriana ( 630-530 Ma). A Faixa Riacho do Pontal representa um ciclo de placas tectônicas completo no Neoproterozoico tardio, envolvendo a colisão do cráton do São Francisco a sul com os blocos litosféricos da Província Borborema a norte.

Palavras chave: Orogênese Brasiliana, Faixa Riacho do Pontal, Cráton do São Francisco

ABSTRACT: TECTONIC AND STRATIGRAPHIC FRAMEWORK OF THE RIACHO DO PONTAL FOLD BELT, PERNAMBUCO-PIAUI-BAHIA BORDER The Riacho do Pontal Fold Belt borders the northern margin of the São Francisco Craton and can be subdivided into three tectonic domains or zones of distinct geology, from north to south: the Internal, Central, and External zones. The Internal Zone is composed by metavulcanosedimentary rocks intruded by plutonic rocks related to the Cariris Velhos Orogeny (Afeição Suite augen-gneiss, 1.0-0.9 Ga); rocks of this age are absent in the other zones. The Central Zone is characterized by the Monte Orebe Complex, composed by metabasalts whose geochemistry is similar to mid-ocean ridge basalts and deep marine metasedimentary rocks. The External Zone is characterized by the Casa Nova nappe system, composed by two units: (a) the Barra Bonita Formation at the base, representing a platformal sequence developed at the northern São Francisco Craton margin; and (b) the Mandacaru Formation at the top, which represents a syn-orogenic deep marine unit. These rocks were affected by compressive deformation (D1-D2-D3) with the development of a south-verging nappe system, during the Neoproterozoic ( $630-575 \mathrm{Ma}$ ), followed by strike-slip deformation (D4) at the late stages of the Brasiliano Orogeny. The whole fold belt is intruded by multiple generations of syn- to post-collisional granitic and syenitic plutons, of Neoproterozoic to Cambrian age ( 630-530 Ma). The Riacho do Pontal Fold Belt represents a complete plate tectonics cycle at the late Neoproterozoic, involving the collision of the São Francisco Craton to the South with the crustal blocks of the Borborema Province towards North.

Keywords: Brasiliano Orogeny, Riacho do Pontal Fold Belt, São Francisco Craton

\section{INTRODUÇÃO}

A Faixa Riacho do Pontal (Brito Neves 1975) bordeja a margem norte do Cráton do São Francisco, na região limítrofe entre os estados da Bahia, Pernambuco e Piauí, e é uma das regiões menos estudadas no contexto das faixas marginais ao cráton (Fig. 1). Essa faixa insere-se no domínio sul da Província Borborema (Brito Neves et al. 2000), uma região caracterizada por intensa atividade magmática, deformacional e metamórfica desenvolvida do Neoproterozoico tardio ao Cambriano ( 630-500 Ma). Muito embora a compreensão da geologia desta área tenha progredido bastante nas últimas décadas, principalmente com a realização dos levantamentos geológicos básicos em escala 1:100.000 da CPRM (Angelim 1988, Gomes H.A. 1990, Figuerôa \& Silva Filho 1990, Mendes \& Silva Filho 1990, Santos \&
Silva Filho 1990, Gomes \& Vasconcelos 1991, Sampaio \& Vasconcelos 1991, Prado \& Vasconcelos 1991) e trabalhos de cunho geofísico (Oliveira 1998, 2008), a região ainda é carente de dados geológicos básicos e apresenta problemas crono-estratigráficos importantes a serem resolvidos.

O principal objetivo deste trabalho é apresentar um arcabouço tectônico e estratigráfico da Faixa Riacho do Pontal, baseado em trabalhos de campo aliados a análises petrográficas dos diversos litotipos envolvidos na faixa. Neste arcabouço, são definidas as principais unidades litoestratigráficas que compõem a faixa dobrada, além de sua geometria e evolução estrutural como um todo. Com base nesses dados, um modelo geodinâmico é proposto nas discussões, como hipótese de trabalho a ser testada por futuros trabalhos de cunho geoquímico, geocronológico e isotópico (Caxito 2013). 


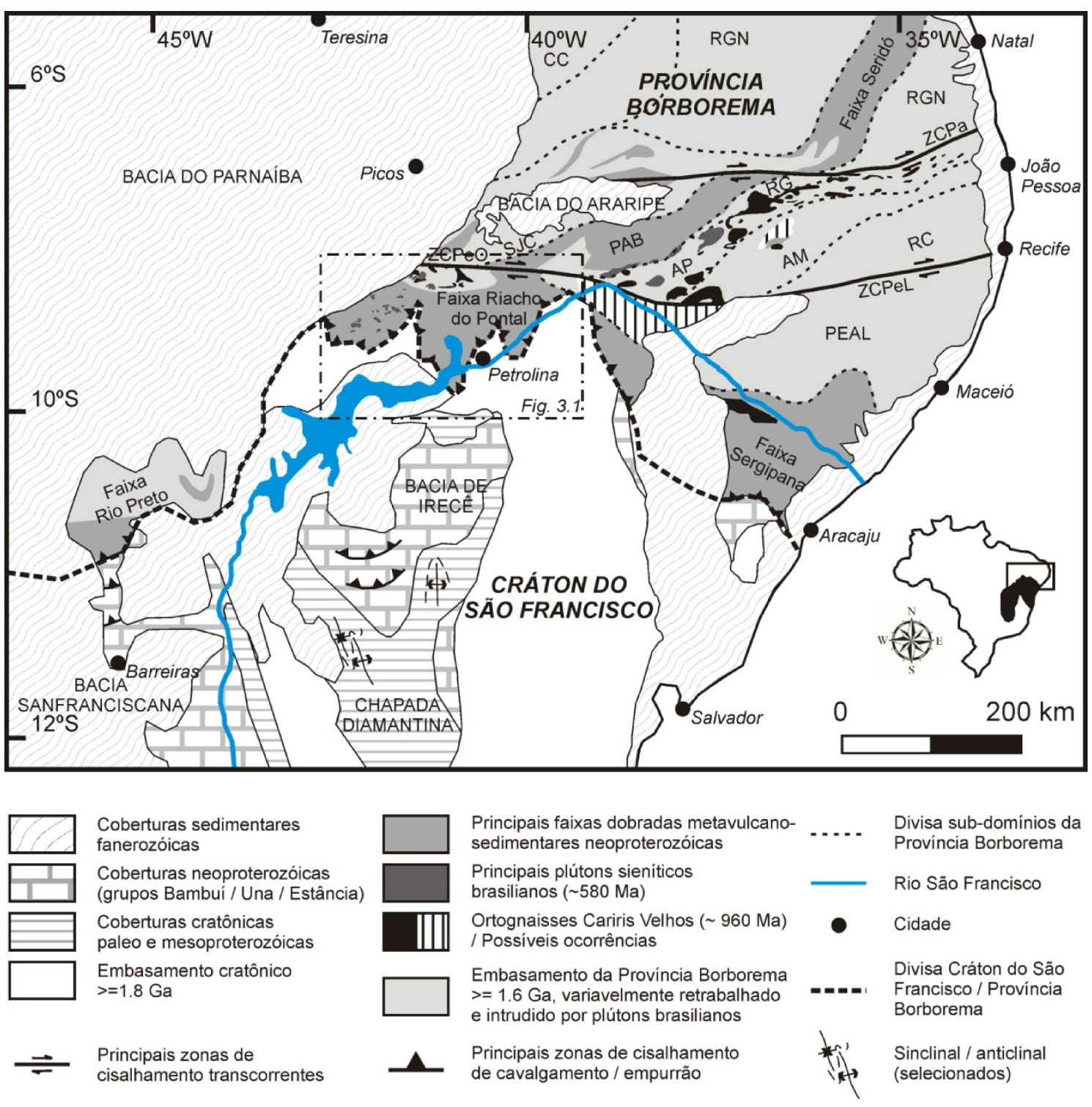

Figura 1 - Mapa geotectônico esquemático de parte do nordeste brasileiro (Caxito 2013).

Sub-domínios da Província Borborema: PEAL - Pernambuco-Alagoas, RC - Rio Capibaribe, AM - Alto Moxotó, AP - Alto Pajeú, PAB - PiancóAlto Brígida, SJC - São José do Caiano, RGN - Rio Grande do Norte, CC - Ceará Central.

$Z C P e O$ e ZCPeL = Zona de Cisalhamento Pernambuco Oeste e Leste, respectivamente; $Z C P a=$ Zona de Cisalhamento Patos. Compilado de Brito-Neves et al. $(2000,2005)$ e referências ali citadas.

\section{ZONEAMENTO TECTÔNICO E ESTRATIGRAFIA}

A Faixa Riacho do Pontal pode ser dividida em três zonas ou domínios, de acordo com as características sedimentares, metamórficas e estruturais contrastantes entre cada domínio (Oliveira 1998). De norte para sul, esses domínios são denominadas de Zona Interna, Central e Zona Externa ou do thrust-and-fold belt (Fig. 3).

Em geral, os contatos entre as diversas unidades estratigráficas descritas a seguir, e também os contatos entre as zonas tectônicas, são de natureza deformacional, caracterizados por zonas de cisalhamento discretas de cinemática predominantemente compressiva (Fig. 2 e 3).

\subsection{Embasamento}

O embasamento da Faixa Riacho do Pontal ocorre tanto na Zona Externa, onde o sistema de nappes Casa Nova cavalga a extremidade norte do Cráton do São Francisco, quanto nas Zonas Central e Interna, onde fatias migmatíticas encontram-se tectonicamente imbricadas junto às rochas supracrustais da faixa (Fig. 2 e 3).

Na região da represa de Sobradinho, a sul dos cavalgamentos frontais da Faixa Riacho do Pontal, predominam ortognaisses do tipo TTG, com bandas tonalíticas / granodioríticas e leucograníticas, variavelmente migmatizados (bloco Sobradinho; Angelim \& Kosin 2001, Dantas et al. 2010). Essas rochas são parcialmente recobertas por diversas 
klippen isoladas das nappes frontais da faixa dobrada, p. ex. a klippe de Barra Bonita (Fig. 2). De maneira geral, a deformação impressa nos ortognaisses é exclusivamente mais antiga do que a deformação da Faixa Riacho do Pontal, predominando foliações de alto ângulo e de direção NNE-SSW (Fig. 3e) e estruturas complexas de superposição de dobras do tipo domo e bacia, cogumelo e laço. Apenas na zona de contato entre as supracrustais e o embasamento, pode ser notada localmente alguma influência de deformação brasiliana, com o desenvolvimento de uma foliação paralela à foliação de baixo ângulo vergente para sul das klippen (Fig. 3f). A maioria dos dados geocronológicos disponíveis sugere uma evolução do bloco Sobradinho durante o Arqueano (3.5-2.5 Ga), com importante retrabalhamento orogênico Paleoproterozoico (2.2-1.9 Ga; Santos \& Silva Filho 1990, Figuerôa \& Silva Filho 1990, Barbosa \& Dominguez 1996, Plá Cid et al. 2000a; Barbosa \& Sabaté 2004; Dantas et al. 2010).

Já nas zonas Interna e Central, o embasamento é caracterizado pelo Complexo Morro do Estreito (Kosin et al. 2004), composto principalmente por ortognaisses tonalíticos a granodioríticos, parcialmente migmatizados (Fig. 4a), com intercalações locais de supracrustais. Este complexo está claramente envolvido e retrabalhado pela deformação brasiliana, com o desenvolvimento de domos polideformados e lascas que cavalgam as supracrustais, com bandamento gnáissico paralelo à foliação brasiliana das mesmas (Fig. 2 e 3). As principais ocorrências são a norte de Afrânio - PE (Serra Dois Irmãos, Fig. 2 e 4a); a norte de Betânia / noroeste de Santa Filomena (PE); e na região de Acauã (PI). Gava et al. (1983) apresentam uma idade $\mathrm{Rb}$-Sr de 1.9 Ga para o corpo a noroeste de Santa Filomena (Morro do Estreito; Fig. 2).

Dessa forma, enquanto nas zonas Central e Interna predomina uma tectônica do tipo casca grossa (thick-skin), com envolvimento do embasamento na deformação brasiliana, na Zona Externa a tectônica é do tipo casca fina (thin-skin), com descolamento das supracrustais de forma relativamente fria sobre seu embasamento e expressiva aloctonia (Fig. 3).

\subsection{Zona Interna}

A Zona Interna da Faixa Riacho do Pontal (Fig. 3) é composta por sequências metavulcanosedimentares (complexos Paulistana, Santa Filomena e Morro Branco), que são intrudidas por várias gerações de suítes ígneas, incluindo: complexos máfico-ultramáficos (de Brejo Seco e São Francisco de Assis), granitos sin-colisionais (suítes Afeição e Rajada) e granitos alcalinos tardi a póscolisionais (Suíte Serra da Aldeia). Esse domínio pode ser subdividido em dois sub-domínios: (a) Paulistana / Santa Filomena, a leste, e (b) Morro Branco, a oeste.

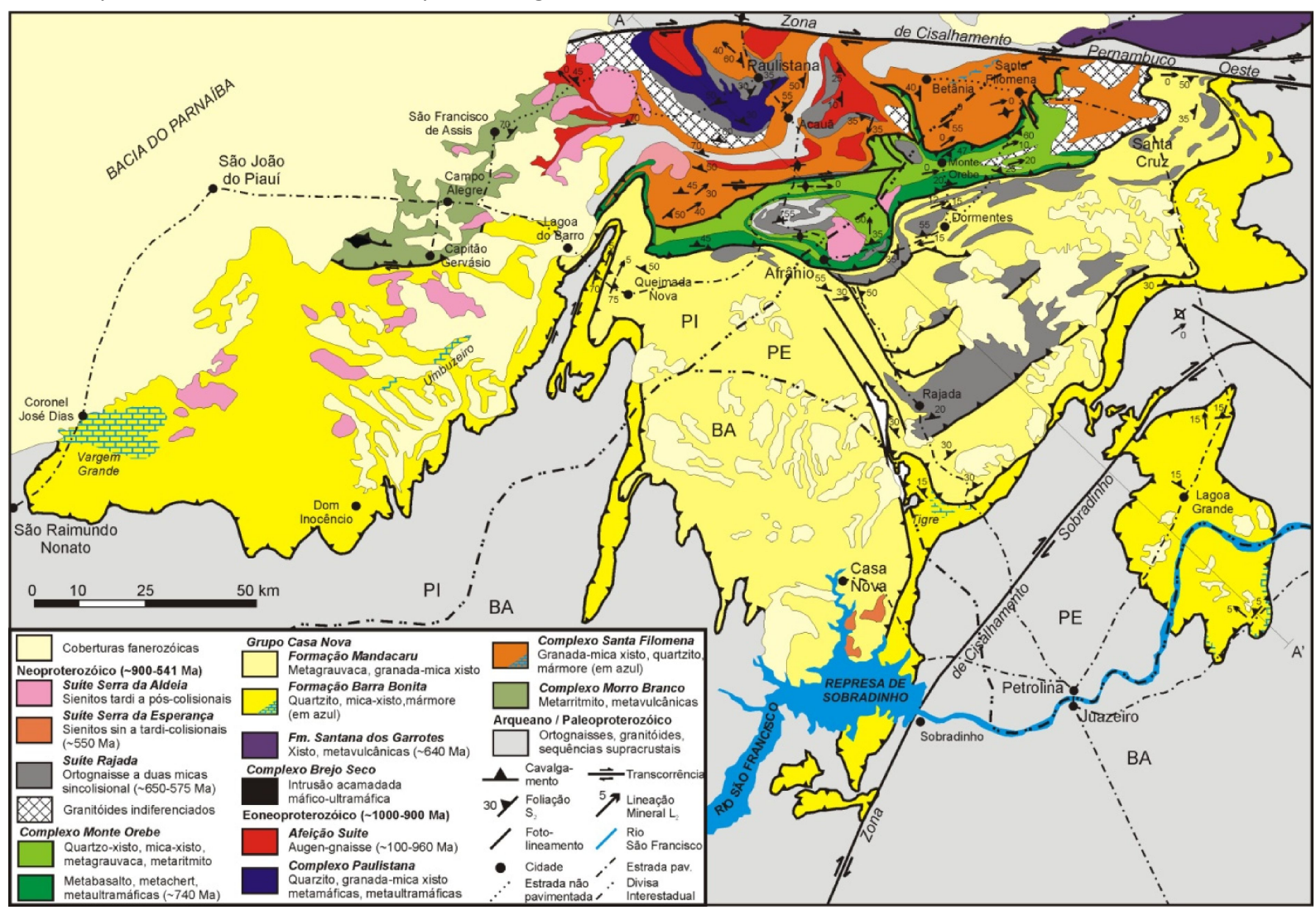

Figura 2 - Mapa geológico simplificado da Faixa Riacho do Pontal (Caxito 2013). Parcialmente compilado dos mapas da CPRM (Angelim \& Kosin 2001 e referências ali citadas). 

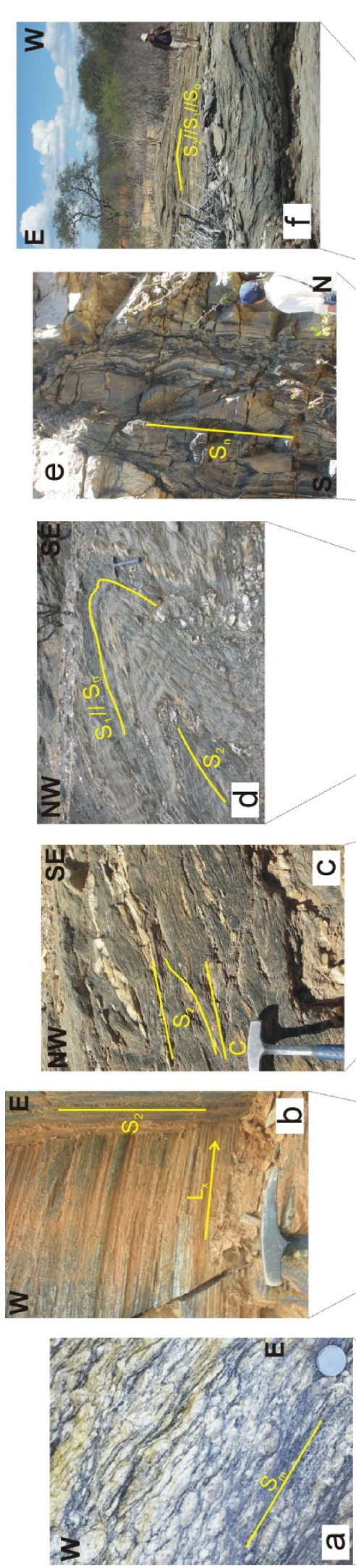
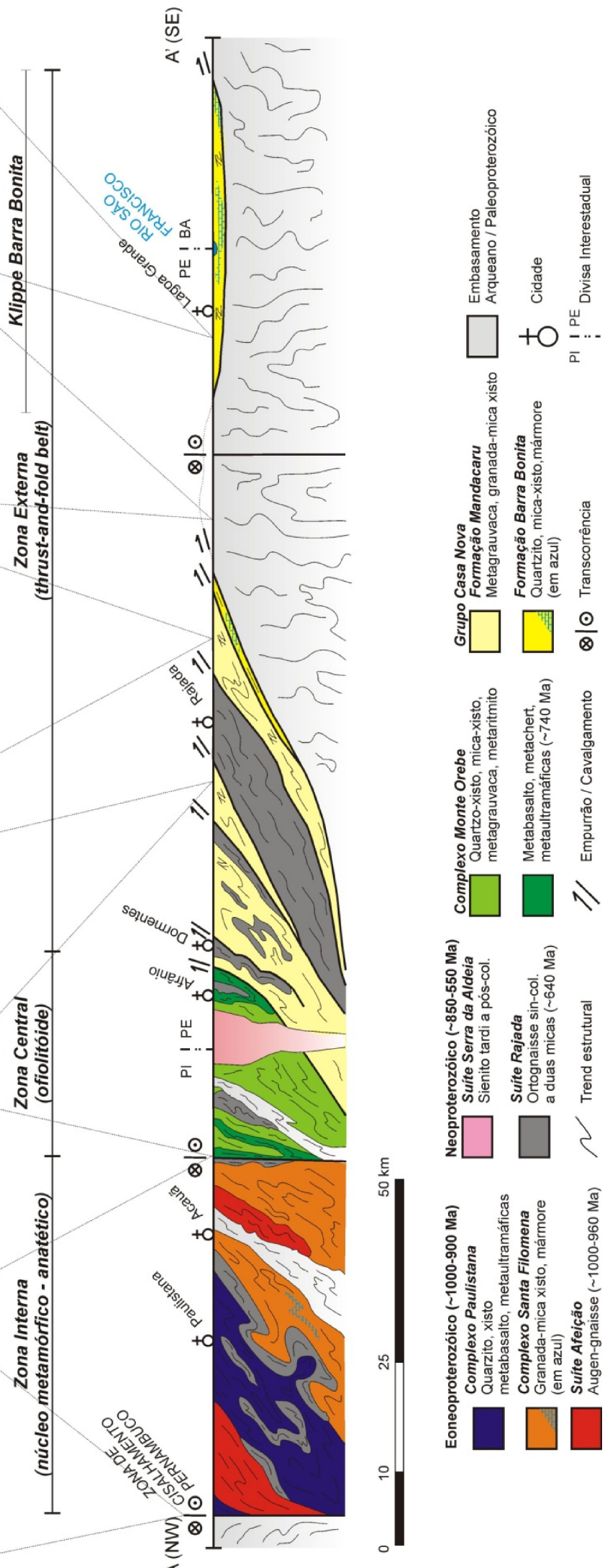

Figura 3 - Seção lito-estrutural da Faixa Riacho do Pontal (traço na Fig. 2). A variação topográfica no perfil é muito pequena para a escala em questão (300 a 500 metros) e por isso não é representada. a) Ortognaisse milonítico do embasamento na Zona de Cisalhamento Pernambuco Oeste; b) Xisto verde do Complexo Monte Orebe com foliação sub-vertical e forte lineação de estiramento direcional (BR-407); c) estruturas S-C desenvolvidas em mica-xisto da Formação Mandacaru, próximo ao thrust basal Pau-Ferro; d) dobra D2 apertada em micaxistos da Formação Mandacaru (estrada Petrolina - Casa Nova); e) Migmatito do embasamento com foliação pré-brasiliana sub-vertical, estrada Jutaí - Lagoa Grande; f) Mica-xisto da Formação Barra Bonita com foliação S2 // S1 // SO sub-horizontal, na klippe de Barra Bonita, estrada Juazeiro - Curaçá. Caxito (2013). 

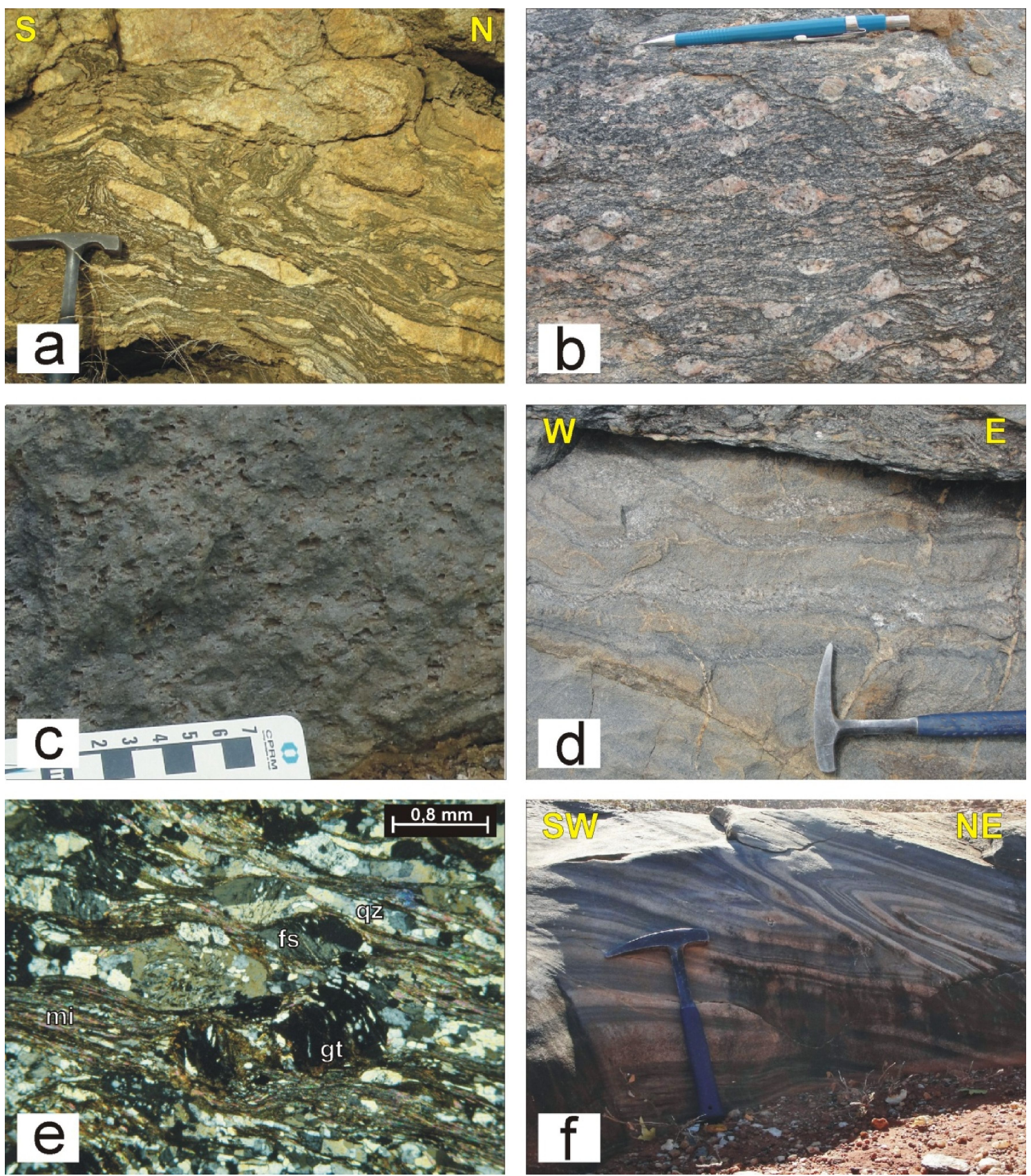

Figura 4 - a) Migmatito do Complexo Morro do Estreito na Serra Dois Irmãos, a norte de Afrânio - PE; b) Augen-gnaisse da Suíte Afeição, estrada Paulistana-Betânia; c) Metabasalto amigdaloidal do Complexo Monte Orebe, Serra do Trancelim, estrada Dormentes - Santa Filomena (PE); d) acamamento rítmico reliquiar em metagrauvaca da Formação Mandacaru, estrada Sussuarana (PI) - Porção do Afrânio

(PE). Camadas pelíticas (granada-mica xisto), de crenulação bem desenvolvida, intercalam-se a camadas arenosas (metagrauvaca); e) aspecto microscópico de granada-mica xisto da Formação Mandacaru, BR407: mi = muscovita; fs = feldspato; gt = granada; qz = quartzo; f) dobras isoclinais em mármore laminado da Formação Barra Bonita, próximo ao povoado Tigre, a sudoeste de Rajada (PE).

\subsubsection{Sub-domínio Santa Filomena / Paulistana}

Gomes \& Vasconcelos (1991) e Angelim \& Kosin (2001) propõem que as unidades metassedimentares (com contribuição vulcânica local) da porção norte da Faixa Riacho do Pontal sejam separadas em duas unidades distintas, os complexos Santa Filomena e Paulistana, em contraste a trabalhos anteriores em que todas essas unidades eram englobadas no Complexo Casa Nova (Angelim 1988). Geralmente, essas unidades estão metamorfizadas na fácies xisto verde médio a anfibolito alto, com um padrão estrutural complexo, pelo menos duas foliações secundárias e dobramento apertado a isoclinal. O Complexo Paulistana apresenta maior quantidade de rochas metabásicas, enquanto essas são apenas esporádicas no Complexo Santa Filomena.

Embora na proposição original, essas unidades representariam fácies integrantes da sedimentação do Complexo Casa Nova (Angelim 1988, Gomes \& Vasconcelos 1991), Angelim \& Kosin (2001) inferem uma idade mesoproterozóica para as mesmas, 
baseados nas idades $\mathrm{U}-\mathrm{Pb}$ e $\mathrm{Rb}-\mathrm{Sr}$ do augen-gnaisse Afeição, em torno de 0.9-1.0 Ga (Jardim de Sá et al. 1988, Van Schmus et al. 1995), e interpretando que esses augen-gnaisses representam rochas intrusivas nesses complexos. Porém, não existem ainda dados geocronológicos confiáveis para esses complexos, e as relações de contato entre os corpos da Suíte Afeição e as rochas encaixantes são apenas parcialmente compreendidas.

\subsubsection{Complexo Santa Filomena}

O Complexo Santa Filomena é a unidade mais extensa da Zona Interna, com bons afloramentos ao redor das cidades de Paulistana (PI), Betânia (PI) e Santa Filomena (PE). Esse complexo é composto principalmente por muscovita-biotita xistos grossos, com frequentes venulações de quartzo, localmente contendo porfiroblastos de granada de até $1.5-2$ $\mathrm{cm}$, cianita, estaurolita, cordierita e/ou sillimanita, além de oligoclásio, e, esporadicamente, turmalina. Intercalações de mármores calcíticos, que gradam para calco-xistos, são também comuns, p. ex. na estrada Betânia - Santa Filomena. Muito localmente, lentes de xisto metabásico ocorrem (tremolitaactinolita xistos, por vezes ricos em granada), especialmente na estrada Monte Orebe (PE) - Acauã $(\mathrm{PI})$, na maioria das vezes altamente intemperizadas. Nas proximidades da Zona de Cisalhamento Pernambuco Oeste, sillimanita-biotita-granada xistos predominam (Fig. 6c). Ocorre ainda, na base do complexo, um horizonte de muscovita-quartzito turmalinífero contendo feldspatos caulinizados, fortemente lineado, em contato com o corpo migmatítico do embasamento (Complexo Morro do Estreito) a norte de Betânia, na estrada Paulistana Betânia (PI).

\subsubsection{Complexo Paulistana}

O Complexo Paulistana (Gomes \& Vasconcelos 1991) é uma sequência metaplutono-vulcanosedimentar que aflora nos arredores da cidade homônima. Essa sequência é composta principalmente por rochas metassedimentares detríticas onde predominam granada-mica xistos prateados a acinzentados, localmente com andaluzita, cordierita e sillimanita; muscovitaquartzo xistos; camadas possantes de muscovita quartzitos, principalmente a sudeste de Paulistana (Serra da Topa); e camadas de metachert, por vezes rico em ferro, espacialmente relacionadas a camadas lenticulares de rochas metabásicas e metaultrabásicas. Localmente, os mica-xistos encontram-se intensamente injetados por veios leucocráticos, conferindo um aspecto migmatítico estromático ou estrutura do tipo lit-par-lit.

A seção metaplutonovulcânica é composta por xistos verdes (metabasaltos) e anfibolitos (metagabros) associados com xistos magnesianos, ultramáficos (talco-xistos, clorita-xistos e tremolititos, às vezes com tremolitas radiais centimétricas). Essas rochas metaígneas afloram em lentes concordantes de dezenas a centenas de metros de espessura, intercaladas nos mica-xistos que predominam no Complexo Paulistana, principalmente na estrada Paulistana - São Francisco de Assis (PI). Boas exposições das máficas e ultramáficas ocorrem nos leitos dos riachos Serra Branca, riacho do Saco, e riacho Moquém, um tributário do riacho Tanquinho, a SW do açude público de Ingazeiro (Paulistana - PI). Os anfibolitos e xistos verdes são compostos principalmente por actinolita-tremolita, hornblenda e plagioclásio parcialmente epidotizado, com augita, quartzo, esfeno, apatita, clorita, biotita e opacos como principais acessórios. Boas exposições de rochas máfico-ultramáficas, metachert e rochas metassedimentares do Complexo Paulistana ocorrem também no sangradouro do açude público de Ingazeiro, em Paulistana (Fig. 7), tectonicamente intercaladas aos gnaisses da Suíte Rajada.

\subsubsection{Sub-domínio Morro Branco}

Entre as cidades de Capitão Gervásio Oliveira e São Francisco de Assis (PI), uma sequência metavulcanosedimentar de baixo grau predomina por aproximadamente $60 \mathrm{~km}$ em uma direção aproximadamente NE-SW (Figura 3.1). Em trabalhos anteriores, todo esse pacote estratigráfico era agrupado sob a denominação "Grupo Brejo Seco" (Gava et al. 1983) ou "sequência metaplutonovulcanosedimentar Brejo Seco" (Marimon 1990). Neste trabalho, essa denominação é preterida em favor da separação dos corpos máficos-ultramáficos intrusivos (a porção "plutônica" da sequência) das rochas metavulcanosedimentares encaixantes, que serão daqui pra frente denominadas Complexo Morro Branco, de acordo com a localidade a oeste de Capitão Gervásio Oliveira (PI), onde essas rochas melhor afloram. Os complexos máfico-ultramáficos de Brejo Seco, a sudoeste, e São Francisco de Assis, a nordeste, representam intrusões plutônicas nessa sequência metavulcanosedimentar e serão tratados separadamente.

\subsubsection{Complexo Morro Branco}

O Complexo Morro Branco é composto principalmente por metarritmitos finamente laminados, quartzo-mica xisto, filito, metachert, quartzito, metabasaltos amigdaloidais, metavulcânicas intermediárias a ácidas, metatufos básicos a ácidos e, localmente, grafita-xisto, esse último especialmente ao redor de São Francisco de Assis.

A seção metavulcânica é dominada por rochas metabásicas, que compreendem metabasaltos 
maciços a foliados, por muitas vezes amigdaloidais, de coloração cinza-esverdeada, parcialmente a intensamente epidotizados. As amígdalas são preenchidas por quartzo, epidoto e carbonatos. Podem ainda ocorrer metabasaltos cisalhados, fortemente foliados, ou maciços, sem a presença de amígdalas. Essas rochas são compostas por actinolita, plagioclásio altamente epidotizado e quartzo, com biotita, clorita, opacos, carbonato, apatita, esfeno, rutilo e leucoxênio como acessórios mais comuns. A actinolita está comumente alterada para biotita e clorita nas bordas. Localmente, a apatita é um acessório abundante.

As metavulcânicas intermediárias a ácidas compreendem metariodacito, metadacito, metariolito e metatufos de cristais. Ocorrem principalmente na região de Morro Branco e a oeste de Mata Pasto, localidades situadas a oeste de Capitão Gervásio Oliveira (PI). São geralmente rochas finas de coloração esverdeada, cinza, esbranquiçada ou amarelada e fortemente xistificadas. São compostas por quartzo, plagioclásio, microclina, sericita, opacos, clorita e biotita. A textura é normalmente porfiroclástica, com feldspatos subédricos a euédricos, imersos em uma matriz orientada fina, às vezes apresentando glass shards devitrificados (Marimon 1990).

\subsubsection{Complexo Brejo Seco}

O Complexo Brejo Seco é uma intrusão máficoultramáfica de tamanho médio, com aproximadamente $10 \mathrm{~km}$ de comprimento na direção $\mathrm{E}-\mathrm{W}$, que está tectonicamente intercalada às rochas metavulcanossedimentares do Complexo Morro Branco, a oeste de Capitão Gervásio Oliveira. Da base para o topo, o complexo é composto por: Uma unidade basal máfica, de pequena espessura (gabros e troctolitos); dunito variavelmente serpentinizado; troctolitos bandados; olivina-gabros esparsos; gabros acamadados; leucogabro; raros anortositos; ilmenita-gabro; e, no topo, um horizonte de ilmenita-magnetitito. 0 complexo inteiro, de aproximadamente $3 \mathrm{~km}$ de espessura, está tectonicamente invertido, com as unidades ultramáficas basais (a norte) acima das unidades máficas de topo (a sul). Diques básicos de granulação fanerítica fina a afanítica intrudem toda a sequência máfica-ultramáfica e podem estar relacionados a atividade magmática tardia rasa, com diabásios amigdaloidais cortando a sequência de gabros acamadados superior.

Dados geoquímicos preliminares foram interpretados como sugestivos de uma afinidade toleiítica relacionada a um arco-de-ilhas para as rochas plutônicas do Complexo Brejo Seco (Marimon 1990). Porém, até agora, não foram realizados estudos sistemáticos sobre a evolução petrogenética e litoquímica do Complexo Brejo Seco. Acima da zona ultramáfica, uma cobertura laterítica espessa é desenvolvida, com importantes depósitos de níquel secundário (Santos 1984).

\subsubsection{Complexo São Francisco de Assis}

Aproximadamente $40 \mathrm{~km}$ a nordeste do Complexo Brejo Seco, ao redor da cidade de São Francisco de Assis, afloramentos esparsos de rochas máficas (gabros) e ultramáficas (serpentinitos) podem ser encontrados, principalmente em ravinas e leitos de drenagens secas, uma vez que essa região é essencialmente plana e muito pobre em afloramentos. Se uma correlação entre os complexos de Brejo Seco e São Francisco de Assis é admitida, então a zona de influência do magmatismo máfico-ultramáfico na porção noroeste da Faixa Riacho do Pontal se estenderia por mais de $60 \mathrm{~km}$ na direção NE-SW. Essa correlação aguarda por confirmação através de análises petrográficas e químicas.

\subsubsection{Suíte Afeição}

Uma das principais características da Zona Interna é a presença de abundantes corpos de augen-gnaisse e granitos pórfiros, englobados na Suíte Afeição (Angelim 1988). Esses granitóides são intrusivos, cavalgam ou servem de embasamento para as rochas supracrustais dos complexos Santa Filomena, Paulistana e Morro Branco, intrudem ortognaisses e migmatitos do Complexo Morro do Estreito, ou são intrudidos e justapostos tectonicamente aos granitóides brasilianos sincolisionais da Suíte Rajada.

A Suite Afeição compreende principalmente augen-gnaisses de composição granítica a granodiorítica, localmente alcançando termos monzo a sienograníticos, compostos por microclina, plagioclásio, quartzo e biotita, com granada, zircão, allanita e turmalina como as fases acessórias principais. Os augen de K-feldspato podem alcançar até $3 \mathrm{~cm}$ de comprimento na matriz fina a média (Fig. 4b).

Os corpos da Suíte Afeição tem formato de diápiros ou alongados, normalmente com uma foliação conspícua anastomosada ao redor de augen de K-feldspato (Fig. 4b). Essa foliação é em geral concordante à foliação principal nas rochas encaixantes. Localmente, porém, a rocha é virtualmente indeformada, principalmente na porção central dos plútons, onde granitos pórfiros podem ser encontrados.

Idades $\mathrm{U}-\mathrm{Pb}$ e $\mathrm{Rb}-\mathrm{Sr}$ indicam que os plútons da Suíte Afeição foram cristalizados em torno de 960988 Ma (Jardim de Sá et al.1988, van Schmus et al. 1995). São ainda necessários estudos petrográficos, litoquímicos e geocronológicos, de forma a 
compreender o papel dessas intrusões na Orogênese Cariris Velhos (Brito Neves et al. 1995; Santos et al. 2010) e na evolução geodinâmica da Faixa Riacho do Pontal e da porção sul da Província Borborema em geral.

\subsection{Zona Central (Complexo Monte Orebe)}

A Zona Central da Faixa Riacho do Pontal é caracterizada por uma estrutura sinformal de direção leste-oeste e aproximadamente $100 \mathrm{~km}$ de comprimento, com 10 a $20 \mathrm{~km}$ de largura na sua porção central, entre as cidades de Afrânio (PE) e Paulistana (PI). Essa chamada "sinforme de Monte Orebe" (Kreysing et al. 1973; Angelim 1988; Moraes 1992) separa as zonas Interna e Externa da faixa dobrada.

O Complexo Monte Orebe é uma sequência metavulcanossedimentar composta principalmente por metavulcânicas básicas (xistos-verdes a actinolita, anfibolitos, metatufos), intercalados a metachert (localmente rico em ferro), granadamicaxisto, metagrauvacas e quartzo-xisto. As camadas de metachert, mais competentes, suportam a topografia de pequenas serras e morrotes entre as cidades de Afrânio e Caboclo (PE), delineando os flancos de dobras normais com eixo ENE-WSW, em contraste aos domínios dominantemente vulcânicos que estão invariavelmente mais intemperizados e suportam uma topografia suave a arredondada na porção central das dobras. Camadas individuais de metachert podem atingir até $3 \mathrm{~m}$ de espessura ( $p$. ex. na rodovia BR-407, próximo à divisa PI-PE), compostas principalmente por quartzo e muscovita, localmente com porfiroblastos de granada e pirita.

As metavulcânicas básicas são os litotipos principais e mais importantes do Complexo Monte Orebe. Comumente são xistos finos a médios de cor verde brilhante, textura nematoblástica e forte deformação, localmente com fábricas miloníticas. Localmente, estruturas vesiculares milimétricas podem ser discernidas em metabasaltos maciços (Fig. 4c). Essas rochas são compostas principalmente por quantidades aproximadamente iguais de anfibólio e plagioclásio, representados por actinolita verde clara e hornblenda, com cristais de 1-5 mm de comprimento, e cristais de andesina de 0.5-1 mm (media de Ab32/An47; Moraes 1992); a intercalação rítmica em camadas milimétricas ricas em anfibólio e camadas ricas em plagioclásio confere um aspecto laminado para essas rochas, em seção delgada. Os principais acessórios são epidoto/zoisita de grão fino, clorita, quartzo, carbonato (principalmente em venulações), esfeno, granada, apatita e zircão. Dados litoquímicos preliminares de elementos maiores e traços selecionados sugerem uma afiliação toleíitica, do tipo MORB, para os protólitos ígneos dos xistos verdes (Moraes 1992).

Rochas metaultramáficas de grão fino e coloração cinza a esverdeada, compostas por talco, serpentina, carbonatos, anfibólios e opacos, ocorrem localmente como lentes intercaladas à sequência metavulcanossedimentar. Ortoanfibolitos de cor verde intensa compostos principalmente por hornblenda e plagioclásio são também comuns, associados aos actinolita-xistos.

Apesar de não existirem ainda dados geocronológicos confiáveis para o Complexo Monte Orebe, análises U-Pb SHRIMP em poucos zircões recuperados de uma rocha metavulcânica sugerem que esse magmatismo tem idade Neoproterozóica, provavelmente em torno de 740 Ma (Brito Neves \& Van Schmus in Brito Neves \& Pedreira 2008). A posição da sequência metavulcânica na porção central da faixa dobrada, as características geofísicas da Zona Central, que sugerem que esta representa uma zona de transição entre dois blocos crustais de densidade e características físicas diferentes (Oliveira 1998), e a geoquímica preliminar do tipo MORB, sugerem conjuntamente que o Complexo Monte Orebe pode conter remanescentes de uma crosta oceânica neoproterozóica, e portanto marcaria uma paleo-zona de sutura (Moraes 1992, Gomes \& Torres 1994, Oliveira 1998, 2008).

\subsection{Zona Externa}

A Zona Externa da Faixa Riacho do Pontal é uma típica faixa de dobramentos de antepaís (foreland fold-and-thrust belt). O modelamento geofísico indica uma baixa espessura de supracrustais nessa zona, com os alinhamentos geofísicos do Cráton do São Francisco contínuos por baixo da cobertura até serem truncados na Zona Central (Oliveira 1998, 2008), caracterizando assim uma protuberância cratônica que foi cavalgada pelas nappes do Grupo Casa Nova.

\subsubsection{Grupo Casa Nova}

O Grupo Casa Nova (Souza et al. 1979, Santos \& Silva Filho 1990, Figuerôa \& Silva Filho 1990, Bizzi et al. 2007) reúne as rochas supracrustais da Zona Externa da Faixa Riacho do Pontal. Esse grupo é composto por duas unidades: formações Barra Bonita e Mandacaru (Santos \& Silva Filho 1990, Figuerôa \& Silva Filho 1990, Bizzi et al. 2007).

\subsubsection{Formação Barra Bonita}

Essa unidade é composta principalmente por rochas metapelíticas de grão fino e muscovita quartzitos, com intercalações lenticulares decamétricas locais, porém abundantes, de mármore calcítico (Fig. 4f). Mica xistos e filitos acinzentados predominam, com quartzo, biotita, 
muscovita, granada, e em menor proporção feldspato, como as fases minerais principais. Os muscovita quartzitos ocorrem principalmente próximo à base da Formação Barra Bonita, em contato com as rochas do embasamento, p. ex. na região da sintaxe de Ponta da Serra, e na estrada Santa Cruz - Lagoa Grande (PE).

As camadas lenticulares de mármore podem atingir até $200 \mathrm{~m}$ de espessura, por exemplo na região de Umbuzeiro, a sul de Capitão Gervásio Oliveira (PI). Na porção extremo oeste da faixa dobrada, próximo a São Raimundo Nonato e Coronel José Dias (PI), os metacarbonatos se tornam muito frequentes, comumente preservando estruturas sedimentares originais. Em Coronel José Dias (PI), carbonatos retrabalhados predominam, com variedades ricas em pisólitos e intraclastos (grainstones e packstones). De forma geral, a Formação Barra Bonita foi classicamente interpretada como uma sequência marinha rasa, plataformal (Santos \& Silva Filho 1990).

Os contatos da Formação Barra Bonita com o embasamento são todos contracionais, na forma de cavalgamentos basais (p. ex. thrust basal Pau-Ferro, nas proximidades do vilarejo homônimo na BR-407), envolvendo forte aloctonia e deslocamentos possivelmente da ordem de dezenas de quilômetros (Fig. 3).

\subsubsection{Formação Mandacaru}

Essa unidade é composta principalmente por mica-xistos com intercalações centimétricas de metagrauvaca (Fig. 4d, e). Os mica xistos, que predominam em volume, são compostos por biotita, muscovita, quartzo, feldspato, porfiroblastos de granada (Fig. 4e) e localmente de estaurolita, com rutilo, zircão, apatita, turmalina e anatásio como os principais acessórios. A metagrauvaca é comumente de cor cinza clara, granulometria média a grossa, com quartzo, muscovita, feldspatos, granada e clorita como minerais essenciais, e minerais acessórios semelhantes aos xistos. Localmente, podem ser observadas estruturas sedimentares nessas metagrauvacas, principalmente na estrada Sussuarana (PI) - Poção do Afrânio (PE), onde o acamamento rítmico com a intercalação entre camadas de metagrauvaca e camadas de granadamica xisto sugere a atuação de correntes de turbidez distais (Fig. 4d).

Um ambiente marinho profundo turbidítico, do tipo flysch, é inferido para a Formação Mandacaru. Dados geoquímicos preliminares suportam essa hipótese, com amostras das metagrauvacas plotando no campo de margem ativa continental em diagramas de ambiência tectônica (Santos \& Silva Filho 1990). Van Schmus et al. (2011) apresentaram dados Sm-Nd em rocha total para amostras da
Formação Mandacaru, com TDM entre 1.4 e 1.6 Ga e $\varepsilon N d(600 \mathrm{Ma})$ de -2.7 a -7.9 .

\section{GRANITÓIDES BRASILIANOS}

\subsection{Magmatismo sin-colisional: Suíte Rajada}

Os metagranitóides da Suíte Rajada são amplamente distribuídos na Faixa Riacho do Pontal, principalmente como corpos estratiformes, concordantes à foliação regional de baixo ângulo das nappes Casa Nova; mas também como corpos de deformação mais complexa, nas zonas Central e Interna, p. ex. no açude público do Ingazeiro, em Paulistana (PI).

A Suíte Rajada é composta principalmente por ortognaisses a duas micas, médios a grossos, mesocráticos, de coloração cinza a esbranquiçada, compostos principalmente por oligoclásio, quartzo, biotita e muscovita, com granada, calcita, epidoto, apatita, esfeno, clorita, zircão e pirita como principais fases acessórias. A textura é principalmente equigranular e lepidoblástica, mas localmente termos microporfiríticos ocorrem. Os corpos são principalmente tabulares, formando camadas centimétricas a batólitos quilométricos, o mais proeminente desses na região de Rajada (PE), com aproximadamente $417 \mathrm{~km} 2(57 \times 12 \mathrm{~km}$ em sua porção mais larga), com bons afloramentos no açude público de Rajada (Fig. 5a).

A característica mais proeminente da Suíte Rajada é uma foliação penetrativa de baixo ângulo, concordante às nappes de mica xistos, diversas vezes com uma lineação mineral down-dip bem marcada por muscovita e biotita, às vezes formando verdadeiros tectonitos L-S. Ocasionalmente, intrusões leucocráticas róseas ocorrem paralelamente e truncando essa foliação, provavelmente relacionados a um estágio magmático tardio (Fig. 5b). Esses veios são compostos principalmente por plagioclásio e quartzo, às vezes com turmalina de granulação pegmatóide. Localmente, esses pegmatitos formam intrusões de porte métrico a decamétrico, geralmente encaixando-se na zona de charneira de dobras isoclinais relacionadas à tectônica de nappes, por exemplo no açude público do Ingazeiro em Paulistana (Fig. 7). Xenólitos de mica xisto e, menos comumente, de rochas metabásicas podem ocorrer.

Angelim (1988) discute as características geoquímicas dos ortognaisses sin-colisionais da Suíte Rajada. As rochas são predominantemente tonalíticas a granodioríticas, com dispersão para os campos dos adamelitos, quartzo-monzodioritos e sienogranitos. Essa variabilidade composicional é também refletido no diagaram TAS (Total Alkalis / Silica), onde as amostras se espalham pelos campos 
cálcio-alcalino e alcalino, e no diagrama de aluminosidade, onde as rochas plotam entre os campos metaluminoso e peraluminoso. Esse padrão de variabilidade composicional é similar aos de granitos derivados de fusão crustal, sem padrões evolucionários claros a partir da diferenciação de magmas máficos. Portanto, os metagranitos da Suíte Rajada devem ter sido gerados em um regime solidus a subsolidus, através do calor produzido pelo empilhamento crustal durante a deformação tangencial da Faixa Riacho do Pontal. A fusão das metagrauvacas e xistos do Grupo Casa Nova é provavelmente a fonte desses magmas (Angelim 1988).

Isócronas $\mathrm{Rb}-\mathrm{Sr}$ em rocha total variam de $743 \pm$ 59 (localidade de Dormentes; Jardim de Sá et al. 1988) a $539 \pm 25$ Ma (localidade de Rajada; Santos \& Silva Filho 1990. A isócrona composta de $667 \pm 10$ Ma apresentada por Jardim de Sá et al. 1992 é uma junção das amostras dessas duas localidades) e representam estimativas grosseiras para a idade de intrusão e metamorfismo da Suíte Rajada e, por extensão, da principal fase de deformação tangencial da Faixa Riacho do Pontal. Evidentemente, idades U-Pb (zircão, monazita) são necessárias para melhor compreender a idade de cristalização e intrusão desses plútons.

3.2.Magmatismo sin- a tardi-colisional: Suíte Serra da Esperança

A Suíte Serra da Esperança compreende sienitos e quartzo-sienitos cinza a róseos, com diques graníticos, pegmatíticos e sieno-graníticos associados, que intrudem as rochas metassedimentares da Zona Externa na região da barragem de Sobradinho, próximo à Casa Nova (BA). As principais fases minerais são K-feldspato pertítico, quartzo, aegirina-augita, diopsídio, esfeno, apatita, biotita magnesiana, winchita-richterita, magnetita (Plá Cid et al. 2000b). Os plútons, que se destacam como pequenas serras em meio a topografia geralmente arrasada (Fig. 5c), são ovais a circulares, com uma foliação de baixo ângulo ou bandamento ígneo, e deformação localizada em zonas de cisalhamento discretas. Apesar da maioria dos corpos não estarem deformados, a orientação preferencial ou microboudinagem de piroxênio, anfibólio e inclusões sin-magmáticas, além de recristalização e alongamento de quartzo e feldspato, são feições que sugerem deformação tectônica, todos consistentes ao deslocamento regional das nappes (foliação vergente para sul, de baixo ângulo), sugerindo possivelmente uma colocação sin a tardi-colisional (Jardim de Sá et al. 1996).

Os sienitos e quartzo-sienitos mostram uma afinidade geoquímica do tipo ultrapotássica, alcalina, e sílica-saturada. Os padrões de elementos terras raras normalizados ao condrito mostram enriquecimento em terras raras leves, sem anomalia verdadeira de Eu. Spidergramas de elementos incompatíves mostram enriquecimentos em elementos LILE (Large Ion Litophile Elements) e anomalias negativas de Nb e Zr (Plá Cid et al. 2000a). Plá Cid et al. (2000a) sugerem que a fonte dos magmas foi um manto previamente metassomatizado, anomalamente enriquecido em terras raras leves e elementos LILE.

Uma isócrona $\mathrm{Rb}-\mathrm{Sr}$ em rocha total de $555 \pm 10$ $\mathrm{Ma}(\mathrm{Ri}=0.7068 \pm 1)$ reportada por Jardim de Sá et al. (1996) é, presentemente, a melhor estimativa para a idade de colocação e deformação da Suíte Serra da Esperança. Essa idade sobrepõe-se, dentro do erro analítico, à idade mais nova obtida por Santos \& Silva Filho (1990) para a Suíte sin-colisional Rajada. Entretanto, estudos geocronológicos mais avançados e modernos são necessários para melhor conhecer as idades de cada fase magmática na Faixa Riacho do Pontal.

3.3. Magmatismo tardi- a pós-colisional: Suíte Serra da Aldeia / Caboclo

A última expressão de atividade magmática na Faixa Riacho do Pontal é representada pela Suíte Serra da Aldeia/Caboclo. Essa unidade ocorre como um conjunto de plútons ovais a circulares, principalmente concentrados na porção noroeste da Faixa Riacho do Pontal, em uma direção NE-SW, bordejando a margem sul da bacia do Parnaíba (Gava et al. 1984). Essa suite é composta por sienitos cinza a róseos, de grão médio a grosso e K-feldspato granitos (Fig. 5d, e, f), localmente porfiríticos, com diopsídio, aegirina, arfvedsonita, riebeckita, hornblenda e biotita como minerais varietais. Os diápiros mostram um caráter isotrópico, localmente com orientação de fluxo ígneo. Deformação localizada em zonas de cisalhamento tardias podem também ocorrer. Dezenas de análises químicas mostram uma afinidade alcalina, com termos peralcalinos/shoshoníticos/potássicos, do tipo A (anorogênico; Gava et al. 1984, Plá Cid et al. 2000a). Os plútons estão intrudidos principalmente nos complexos Casa Nova, Morro Branco e Santa Filomena, na maioria das vezes produzindo padrões deformacionais nas rochas encaixantes, relacionados à colocação dos diápiros largos, ovóides. O maior desses corpos é um plúton circular entre Paulistana e São Francisco de Assis, com $84 \mathrm{~km} 2$, e um raio de aproximadamente $5,5 \mathrm{~km}$ (Fig. 2). 

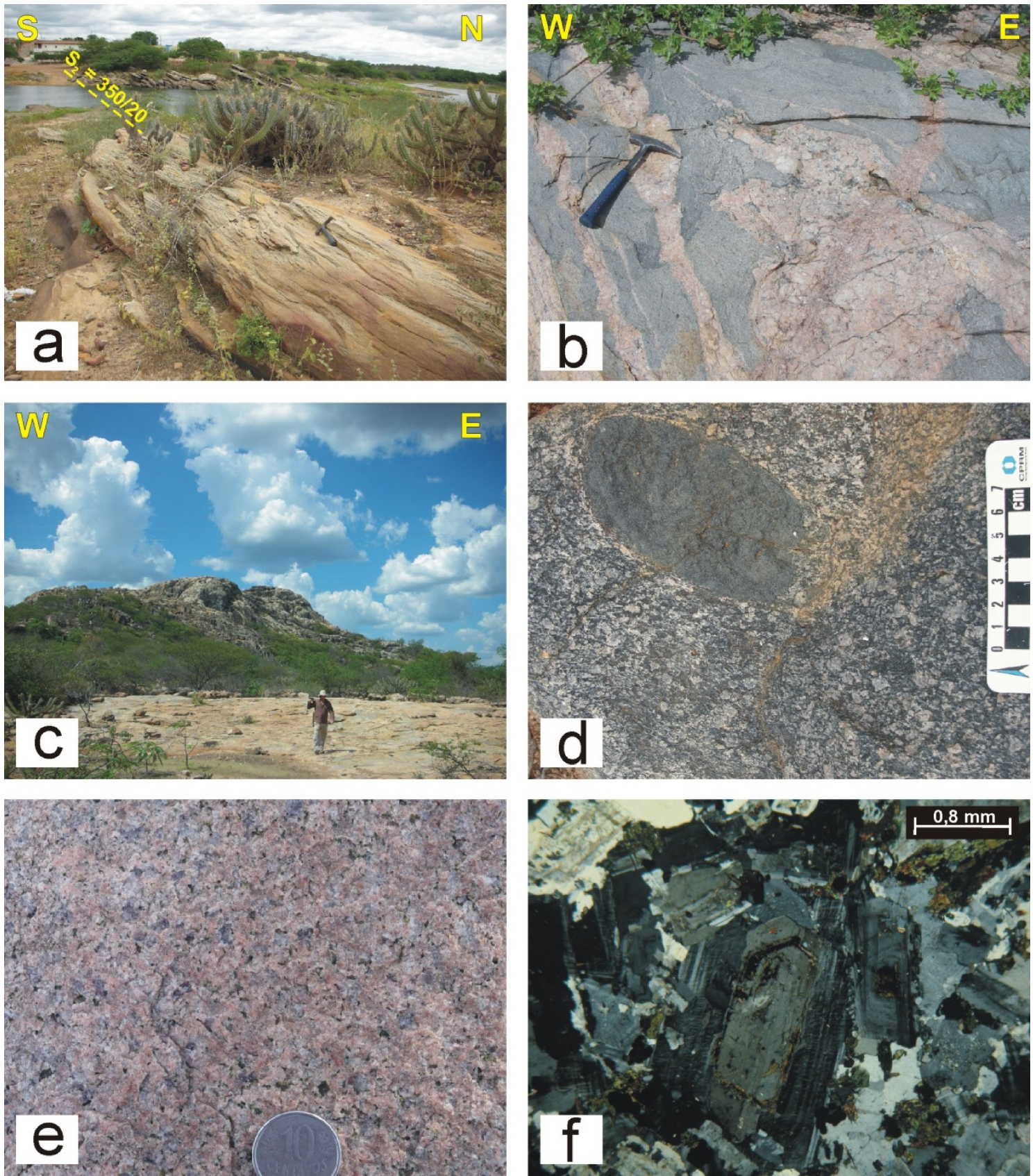

Figura 5 - a) Granito mesocrático foliado, a duas micas, da Suíte Rajada, no açude da cidade homônima; b) granito mesocrático da Suíte Rajada, com intrusão sin-deformacional de granitóide pegmatítico róseo, rico em turmalina, no leito do Rio Canindé; c) sienito da Suíte Serra da Esperança, na serra homônima nas margens da represa de Sobradinho, Casa Nova (BA); d) Encrave máfico em granitóide da Suíte Caboclo, plúton homônimo a leste de Afrânio (PE), vilarejo Caboclo; e) detalhe de quartzo-sienito róseo da Suíte Serra da Aldeia, estrada Paulistana - São Francisco de Assis (PI); f) aspecto microscópico, sob nicóis cruzados, de quartzo-sienito da Suíte Serra da Aldeia, com destaque para fenocristais de K-feldspato zonados.

Na cidade de Caboclo (PE), o pluton semi-circular homônimo intrude as rochas metavulcanosedimentares do Complexo Monte Orebe, causando uma deformação relacionada à sua colocação (do tipo balão). Aproximadamente $7 \mathrm{~km}$ a nordeste ocorre o plúton de Nova Olinda, em forma de cunha. Ambos os plutons são compostos por sienito a sienogranito, com feldspato potássico, mica marrom a verde, plagioclásio, diopsídio, augita e quartzo como minerais essenciais; os acessórios mais abundantes são apatita, titanita, epidoto magmático, allanita, zircão e magnetita. Encraves ricos em micas e piroxênio são comuns (Fig. 5d).

A assinatura geoquímica de ambos os plútons da Serra da Aldeia e de Caboclo / Nova Olinda é similar à da Suíte Serra da Esperança (Gava et al. 1984, Ferreira et al. 1994, 1998; Plá Cid et al. 2000a), também mostrando enriquecimento em terras raras leves, sem verdadeira anomalia de Eu, e uma anomalia negativa de Nb. Ferreira et al. (1998) 
analisaram a composição isotópica de oxigênio ( $\delta 180 V-S M O W)$ de amostras dos plútons Caboclo e Nova Olinda, com valores entre +10 e $+11.4 \%$, além de um TDM de $1.8 \mathrm{Ga}$, dessa forma implicando altas taxas de contaminação por componentes crustais.

\section{GEOLOGIA ESTRUTURAL E METAMORFISMO}

As estruturas da Faixa Riacho do Pontal podem ser agrupadas em 4 fases de deformação principais, D1, D2, D3 e D4 (Angelim 1988, Gomes F.E.M. 1990, Gomes \& Vasconcelos 1991). As fases D1, D2 e D3 podem ser compreendidas como fases progressivas de um mesmo regime tectônico compressivo, com transporte de massa predominantemente para sul (vergente em direção ao cráton do São Francisco), enquanto a fase D4 relaciona-se às estruturas transcorrentes do Brasiliano tardio, cuja principal feição é a Zona de Cisalhamento Pernambuco Oeste. Embora por algum tempo as estruturas D1-D2-D3 foram interpretadas como geradas por um evento compressivo de idade Paleoproterozóica ("Transamazônico") e somente a fase transcorrente D4 era atribuída ao Brasiliano, com o advento das datações radiométricas $\mathrm{Rb}-\mathrm{Sr}$, Jardim de Sá et al. (1992) reconheceram que todas essas fases devem estar ligadas à Orogênese Brasiliana, do Neoproterozoico terminal.

\subsection{Regime Compressivo}

Durante esse regime implantaram-se as megaestruturas tangenciais da Faixa Riacho do Pontal, com vergência principal para S, SSW e SSE, em direção à protuberância norte do Cráton do São Francisco. Esta protuberância atuou como um edentador rígido, gerando as formas externas da faixa dobrada, tais como a Sintaxe de Ponta da Serra, e diversas virgações. Diversas klippen espalhadas na região de barragem de Sobradinho atestam a extensão prévia das nappes Casa Nova.

\subsubsection{Fase D1}

Essa fase gerou a foliação $\mathrm{S} 1$, que na grande maioria dos casos é marcada pelo alinhamento e achatamento de minerais micáceos e tabulares paralelamente ao acamamento sedimentar, SO. As dobras F1, das quais S1 é plano axial, manifestam-se como dobramentos intrafoliais, sem raízes, apertados a isoclinais, delineados tanto por so quanto por venulações quartzosas, de forma geral vergentes para sul.

Tanto a superfície S1 quanto as dobras F1 são superpostas de forma quase paralela pelas estruturas da fase D2, que transpôs fortemente essas estruturas anteriores, gerando padrões de dobramento em laço. Dessa forma, a Fase D1 provavelmente corresponde a um evento cedo- tectônico que precedeu o incremento deformacional mais forte que viria a ser implantado com a Fase D2.

Em escala microscópica, a foliação S1 está preservada como trilhas de inclusões sinuosas em porfiroblastos de granada, discordantes à foliação externa (S2). Também podem ser encontrados porfiroblastos compostos de granada, com núcleo contendo inclusões de S1 e bordas mais límpidas, sin-cinemáticas a D2 (Fig. 6a). Dessa forma, as condições do metamorfismo $\mathrm{M} 1$, concomitante à D1, devem ter atingido a fácies xisto verde alto a anfibolito baixo, com desenvolvimento da paragênese granada+ biotita + muscovita + quartzo em metapelitos.

\subsubsection{Fase D2}

A Fase D2 é a mais importante na estruturação da Faixa Riacho do Pontal, com a geração da foliação de crenulação penetrativa S2, paralela ao plano axial de dobras fechadas a isoclinais de S1 // SO (Fig. 3c). Regionalmente, o desenvolvimento de S2 é contemporâneo ao empilhamento das nappes Casa Nova, vergentes para sul, sobre a margem norte do Cráton do São Francisco, à fusão crustal e colocação das intrusões sin-colisionais da Suíte Rajada, e ao metamorfismo de fácies xisto verde superior a anfibolito, que é reverso nas nappes (nappes superiores mostram metamorfismo de mais alto grau que as inferiores). Dessa forma, as macroestruturas contracionais da faixa dobrada relacionam-se a D2, por exemplo, os traços das zonas de cavalgamento frontais ou oblíquas, tal como o thrust basal Pau-Ferro a sul da cidade homônima; a Sintaxe de Ponta da Serra; os testemunhos estruturais tal como a klippe de Barra Bonita; etc (Fig. 2).

Os fronts de empurrão das nappes são normalmente marcados por estruturas do tipo S-C (Fig. 3c) e desenvolvimento de milonitos com granadas rotacionadas sin-deformacionais, micafish, etc. Localmente, desenvolvem-se dobras em bainha associadas a uma forte lineação de estiramento de sentido norte-sul e caimento para norte (Fig. 5b). Boudins de camadas relativamente mais competentes e microboudinage de cristais de hornblenda nas rochas máficas são comumente associados a D2.

Além do deslocamento em rampas frontais na forma de nappes, a deformação foi também acomodada na forma de rampas laterais e oblíquas, principalmente de direção N-S (p. ex. na Sintaxe de Ponta da Serra), NW-SE e NE-SW; e zonas de escape lateral E-W, principalmente na porção central da faixa dobrada, com o desenvolvimento da megasinforme de Monte Orebe na Zona Central. 

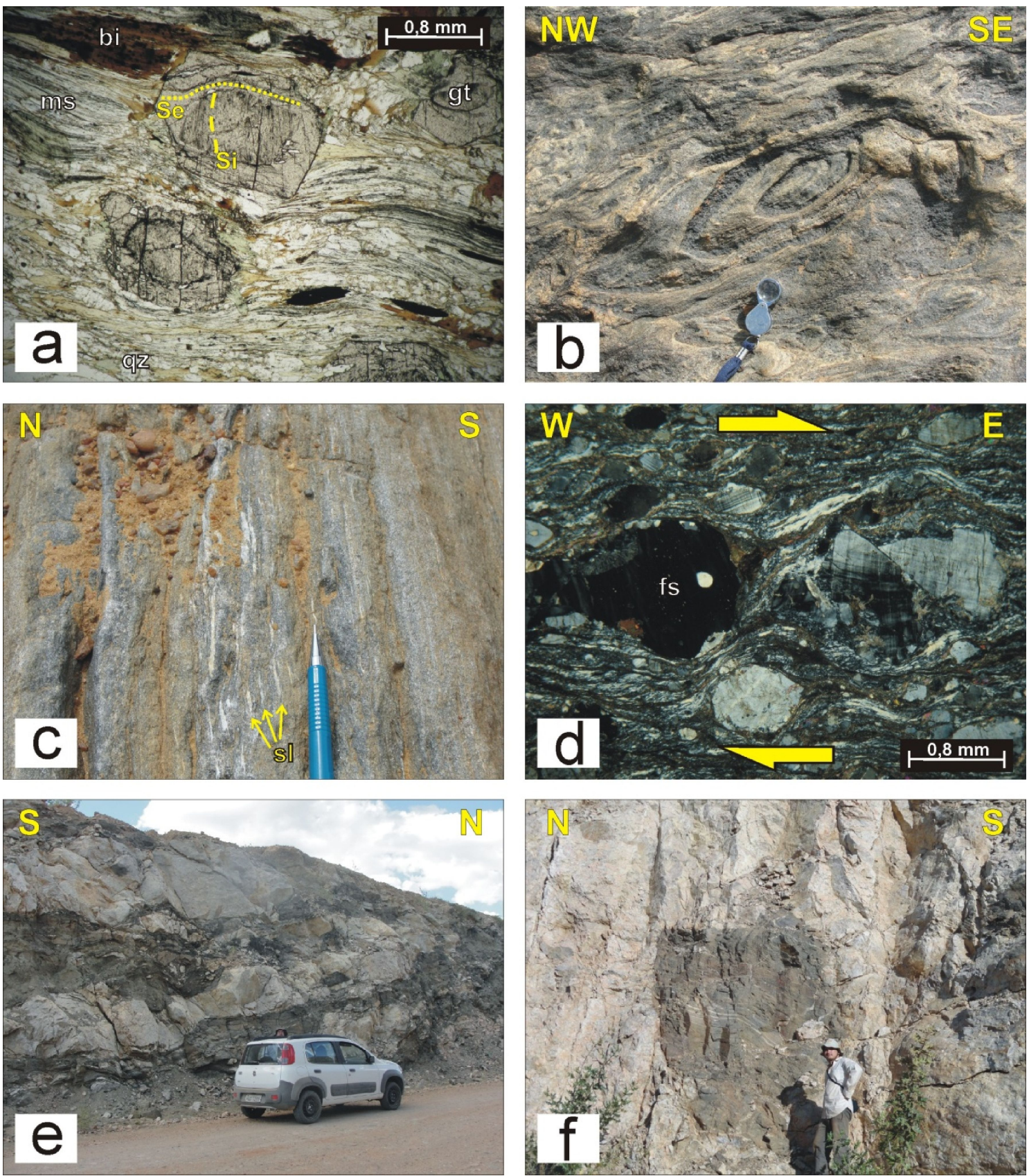

Figura 6 - a) Fotomicrografia sob nicóis paralelos de granada-mica xisto da Formação Mandacaru, mostrando uma foliação interna preservada como trilhas de inclusões sinuosas nos núcleos dos porfiroblastos de granada (Si = S1), truncada pela foliação externa (Se = S2) que se desenvolveu concomitantemente à blastese das bordas pobres em inclusões das granadas. Ponta da Serra, estrada Queimada Nova

- Lagoa do Barro;b) Dobra em bainha (D2) em metagrauvaca da Formação Mandacaru, indicando transporte tectônico para sul; c) Sillimanita-granada-mica xisto do Complexo Santa Filomena, na zona de cisalhamento Pernambuco Oeste. Agregados de sillimanita sin-D4

(sl) em destaque; d) Aspecto microscópico de augen-gnaisse milonítico da Suíte Afeição a nordeste de Paulistana (PI), com cristais de

feldspato fraturados (book-shelf) indicando deformação destrógira na Zona de Cisalhamento Pernambuco Oeste; e) mica xisto / paragnaisse do Complexo Santa Filomena (cor escura) intensamente injetado por intrusões graníticas leucocráticas sin-colisionais (Suíte Rajada), no núcleo metamórfico / anatético da faixa Riacho do Pontal, na Zona Interna, estrada da Odebrecht, a nordeste de Paulistana

(PI); f) Xenólito de paragnaisse no seio da massa granítica leucocrática, na mesma localização de (e).

Uma lineação mineral ou de estiramento, L2, é comum no sistema de nappes, normalmente com mergulho down-dip na Zona Externa. Nas zonas Central e Interna, porém, as atitudes oblíquas a direcionais de L2 sugerem uma cinemática mais complexa, onde intenso escape lateral pode ter ocorrido concomitantemente à tectônica predominantemente tangencial da Zona Externa.
Essas lineações são particularmente bem desenvolvidas nos plútons sin-colisionais da Suíte Rajada, geralmente de formato tabular e paralelos à foliação S2 nas rochas encaixantes (Fig. 5a).

As estruturas deformacionais do tipo dobras de nappe são muito bem exemplificadas no sangradouro do açude público do Ingazeiro, em 
Paulistana (Fig. 7). Neste afloramento, rochas do Complexo Paulistana cavalgam os granitos sincolisionais da Suíte Rajada (Fig. 7 a, b). As camadas relativamente menos competentes de granada-mica xisto, xistos ultramáficos (talco-xistos e tremolititos), granada-anfibólio xisto e metachert do Complexo Paulistana formam dobras isoclinais a recumbentes de flanco rompido, vergentes para sudoeste, que evoluíram para thrust folds cavalgantes sobre os granitos mesocráticos da Suíte Rajada (Fig. 7a, b). Nas zonas de charneira das dobras do Complexo Paulistana, alojam-se granitos leucocráticos sincinemáticos, de granulação pegmatítica e ricos em turmalina (Fig. 7a). Esses granitos leucocráticos alojam-se também na foliação do granito mesocrático, por vezes formando boudins. Essas dobras isoclinais são ainda redobradas por um evento posterior (D3) que gera dobras abertas de menor amplitude (F3), com eixo mergulhante para NW (Figura 7c), e uma clivagem de crenulação subvertical de direção NW-SE (S3).

O metamorfismo principal da Faixa Riacho do Pontal, que atinge a fácies anfibolito alto, é principalmente concomitante à $\mathrm{D} 2$, porém as condições metamórficas foram mantidas por algum tempo após o cessamento das tensões compressivas, como exemplificado por pseudomorfos de estaurolita substituídos por minerais micáceos, que sobrecrescem D2 (Gomes F.E.M. 1990).

Porfiroblastos de estaurolita, cordierita, cianita e sillimanita, nas nappes mais internas da zona Externa, na Zona Central e na Zona Interna, atestam que o metamorfismo chegou à fácies anfibolito na porção central da faixa. A passagem da zona da granada para a zona da estaurolita parece ocorrer nos arredores de Afrânio, com bons afloramentos contendo porfiroblastos de estaurolita na Zona Central, principalmente na região de Barra do Meio, a norte de Caboclo. Já a passagem para a zona da sillimanita parece ocorrer no limite da Zona Central com a Zona Interna.

Na região de Santa Cruz (PE), Almeida \& Lima (1996) apresentaram dados geotermobarométricos usando o geotermômetro de troca catiônica no FeMg no par biotita-granada e o geobarômetro baseado no equilíbrio de $\mathrm{Ca}$ entre granada e plagioclásio, que forneceram temperaturas na ordem de 300-600 C e pressões de 4-9 kbar para as associações de núcleo e 400-500 C e 5-7 kbar para as composições de borda dos minerais. Para rochas anfibolíticas intercaladas nos metapelitos, foram obtidas temperaturas de 540-590 C e pressões de 5-6 kbar, usando o geotermobarometro anfibólioplagioclasio. Dessa forma, o metamorfismo atingiu o seu ápice na facies anfibolito médio a alta na região norte da faixa dobrada, com reações retrometamórficas provavelmente ligadas ao soerguimento e erosão do pacote orogênico após o pico da deformação D2.

Nas zonas Central e Interna, é comum o desenvolvimento de zonas intensamente migmatizadas, com abundante intercalação de leucossomas quartzo-feldspáticos à massa xistosa dos afloramentos (Fig. 6e, f). Tratam-se de migmatitos estromáticos ou com estruturas do tipo lit-par-lit, isso é, com leucossomas em camadas centimétricas e descontínuas, geralmente paralelas à foliação regional. Os xistos encaixantes representam o paleossoma, ou seja, as intrusões provavelmente são geradas externamente à massa xistosa. As camadas psamíticas (quartzitos e metagrauvacas) em contato normalmente não são migmatizadas. Essas zonas migmatíticas podem estar relacionadas aos efeitos de fusão crustal e geração dos granitos sin-colisionais da Suíte Rajada, como observado nos cortes da ferrovia Transnordestina, em construção (estrada da Odebrecht), a nordeste de Paulistana (PI), onde belíssimos afloramentos de xistos estromáticos com intrusões graníticas exemplificam essa zona de anatexia típica do núcleo orogênico (Fig. 6 e, f).

\subsubsection{Fase D3}

Essa fase tem desenvolvimento apenas local e significa, provavelmente, um incremento progressivo de deformação em relação à Fase D2. É responsável pelo desenvolvimento de uma clivagem de crenulação espaçada, bem visível nos xistos verdes do Complexo Monte Orebe, além de localmente nas rochas metapelíticas Casa Nova, sendo particularmente bem desenvolvida na klippe de Barra Bonita.

Apesar de ter atitude muito variável, o máximo modal dos planos indica uma atitude 335/60; dessa forma coerente com a tectônica tangencial da faixa dobrada. Porém, planos com caimento de ângulo alto para os quadrantes NE e SW são também comuns (p. ex. no açude público do Ingazeiro), talvez indicando um par cisalhante conjugado, desenvolvido em condições rúpteis-dúcteis, ou seja, mais rasas do que a deformação D2.

O metamorfismo ligado à fase D3 envolve apenas reações retrometamórficas para a fácies xisto verde, tais como a substituição da biotita nas bordas de granada por clorita.

\subsection{Regime Transcorrente - Fase D4}

Essa fase é representada pela movimentação destrógira transcorrente em zonas de cisalhamento de direção $E-W$, das quais a Zona de Cisalhamento Pernambuco Oeste é a estrutura mestre (Fig. 1, 2 e 3). Essa zona de cisalhamento de escala continental causa a milonitização de todas as unidades cortadas 
por ela, dessa forma gerando milonitos de alto grau, compostos por sillimanita-biotita-granada xistos (Complexo Santa Filomena; Fig.6c); além de milonitos de rochas ortognáissicas do embasamento (Fig. 3a) e dos augen-gnaisses da Suíte Afeição (Fig. 6d).

A deformação nos arredores e dentro da zona de milonitização é altamente complexa, com o desenvolvimento de estruturas em flor e mergulhos variáveis da foliação milonítica. Nos arredores da Zona de Cisalhamento Pernambuco Oeste, pode ser observada ainda uma clivagem de crenulação subvertical de direção $\mathrm{E}-\mathrm{W}$, que é plano axial de dobras abertas de S2 com eixo vertical, nos mica xistos dos complexos Paulistana e Santa Filomena. Essas dobras são na verdade parasíticas de grandes dobras de arraste geradas na porção extremo norte da Zona Interna, que atestam para o sentido destrógiro da Zona de Cisalhamento Pernambuco Oeste.
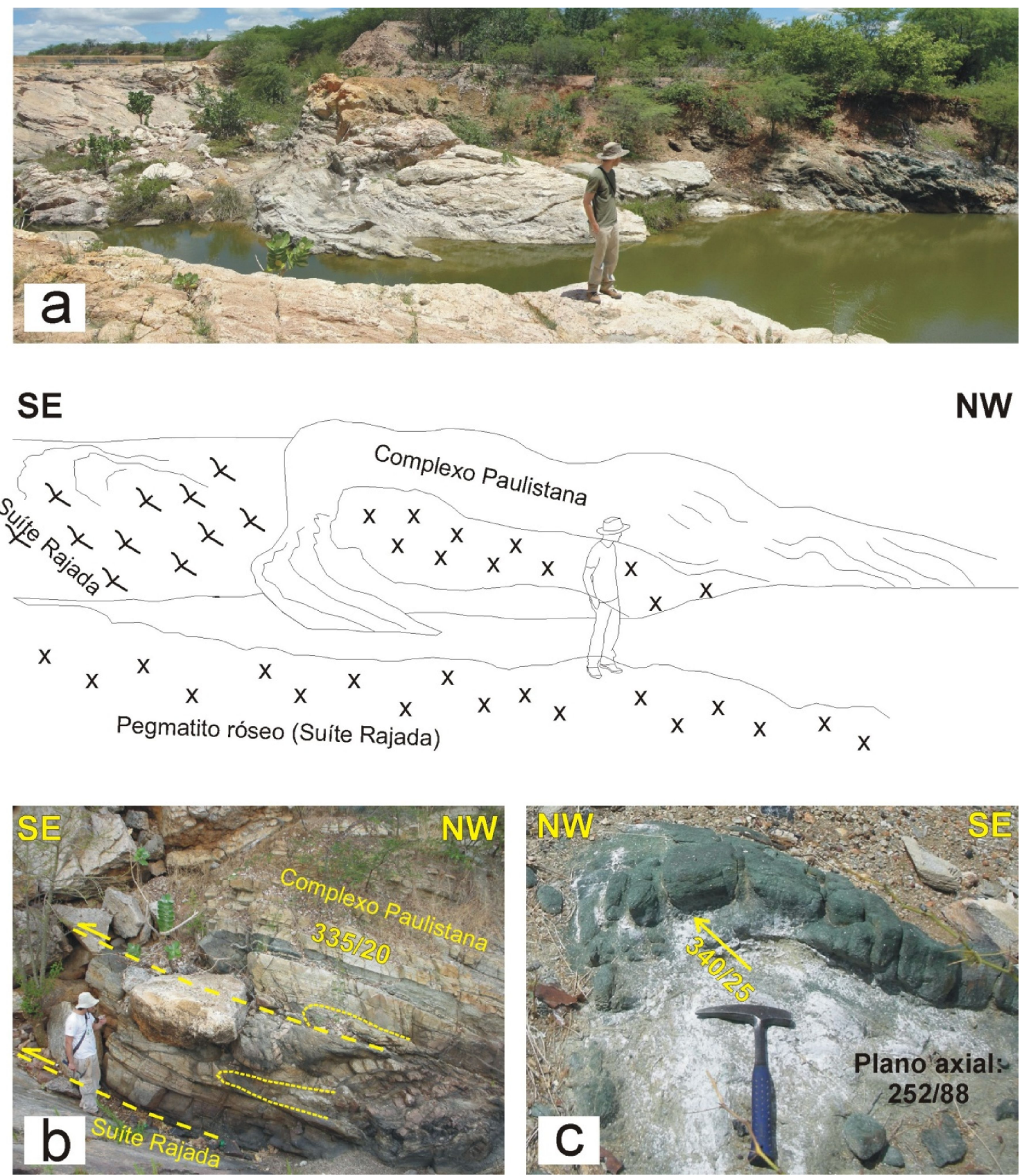

Figura 7 - Estruturas da fase compressiva no açude público do Ingazeiro, Paulistana. a) Dobra de nappe (nappe fold) envolvendo metaultramáficas e metassedimentares (mica xisto e chert) do Complexo Paulistana. Na charneira da dobra, alojou-se um granito pegmatítico turmalinifero, sin-colisional, relacionado à Suíte Rajada. A sudeste, a nappe cavalga um granito mesocrático a duas micas tipo Rajada, que também é intrudido pelo pegmatito róseo; b) geometria dos empurrões, com geração de dobras isoclinais a assimétricas, de

flanco curto rompido, relacionadas à falhas de empurrão com transporte tectônico para sudeste; c) dobra tardia (D3?) em xisto metaultramáfico do Complexo Paulistana. Essas dobras normais horizontais, suaves, se superpõem às dobras isoclinais a recumbentes da tectônica de nappes D2 (Caxito 2013). 
Um grande número de zonas de cisalhamento sub-verticais de direção E-W nas zonas Central e Interna, facilmente observáveis na estrada Afrânio Acauã - Paulistana, é aqui considerado também como gerado nessa fase, embora em trabalhos anteriores essas estruturas tenham sido consideradas como relacionadas ao escape lateral durante a fase D2 (Gomes F.E.M. 1990, Gomes \& Vasconcelos 1991). Essas estruturas comumente transpõem todas as estruturas tangenciais mais velhas, gerando uma foliação milonítica sub-vertical penetrativa, com uma lineação de estiramento mineral direcional E-W associada (Fig. 3b), marcada pela orientação de minerais micáceos e estiramento de anfibólios, turmalina, etc. O desenvolvimento de porfiroblastos de granada sin-cinemáticos indica a movimentação destrógira dessas zonas de cisalhamento subsidiárias, de maneira similar à Zona de Cisalhamento Pernambuco Oeste.

Através de análises por microssonda eletrônica, Vauchez \& Egydio-Silva (1992) estimaram as condições de temperatura e pressão na Zona de Cisalhamento Pernambuco Oeste entre 630-700 C e 6 kbar, dessa forma, na transição entre as fácies anfibolito alto e granulito, o que é consistente com a fusão parcial e colocação de magmas sincinemáticos à zona de cisalhamento, além do desenvolvimento de xistos a sillimanita. Para leste, a Zona de Cisalhamento Pernambuco diverge em numerosos ramos de direção NE-SW, em um splay do tipo rabo-de-cavalo, que resolve a deformação transcorrente em uma larga zona transpressional, nos arredores de Floresta, PE (Vauchez \& EgydioSilva 1992). Dessa forma, essa zona de cisalhamento profunda, que representa uma importante descontinuidade crustal (Oliveira 2008), não tem continuidade no ramo leste da Zona de Cisalhamento Pernambuco Leste, que representa uma estrutura mais rasa e descontínua (Neves \& Mariano 1999). Por outro lado, a continuação da Zona de Cisalhamento Pernambuco Oeste na Zona de Cisalhamento Congo de direção NE-SW, na Zona Transversal, parece uma hipótese mais provável do ponto de vista geofísico (Oliveira 2008).

\section{DISCUSSÃO E MODELO GEODINÂMICO}

De acordo com os dados litoestratigráficos e estruturais apresentados e com o zoneamento tectônico proposto para a faixa dobrada, um modelo de evolução geodinâmica pode ser proposto tentativamente (ver também Caxito 2013). Neste modelo, a faixa Riacho do Pontal representa um orógeno colisional desenvolvido devido à colisão entre o Cráton do São Francisco, a sul, e um bloco crustal da Província Borborema, a norte. Esse último é caracterizado pela presença de rochas relacionadas à Orogênese Cariris Velhos ( 1000-920
Ma), que estão ausentes no primeiro. Dessa forma, a Zona Interna representa parte do bloco continental da Província Borborema que colidiu com o cráton do São Francisco no Neoproterozoico, provavelmente o extremo oeste do bloco de Pernambuco - Alagoas (Fig. 1). A Zona Externa representa a margem norte do Cráton do São Francisco e suas sequências plataformais (Fm. Barra Bonita), e a Zona Central representaria a zona de sutura entre esses dois blocos, onde encontram-se possíveis remanescentes de assoalho oceânico (Complexo Monte Orebe).

O modelo geodinâmico se desenvolveria aproximadamente nas seguintes etapas:

a) 960-740 Ma-Estágio de rifteamento inicial

Rifteamento crustal devido à colocação de uma possível pluma mantélica, que gerou as intrusões máfico-ultramáficas de Brejo Seco e São Francisco. Esses corpos atravessaram principalmente crosta relacionada à Orogênese Cariris Velhos na Zona Interna, que pode representar uma continuação do Terreno Alto Pajeú da Zona Transversal (Fig. 1).

\section{b) 740 - 630 Ma-Estágio de margem passiva}

Com a continuação do estiramento crustal, uma extensa margem passiva desenvolveu-se na margem norte do Cráton do São Francisco (Fm. Barra Bonita). Verdadeira crosta oceânica é desenvolvida e preservada como os metabasaltos do Complexo Monte Orebe.

\section{c) 630-620 Ma - Estágio de subducção}

Instalação de uma zona de subducção entre os blocos do São Francisco e Pernambuco - Alagoas, marcando o local de consumo da maior parte da crosta oceânica Monte Orebe. Lascas obductadas de metabasaltos do tipo MORB, marcam o local dessa antiga zona de sutura. Na Zona Transversal, entre o bloco da Borborema Norte e o bloco de Pernambuco - Alagoas, ocorrem múltiplas intrusões de plútons cálcio-alcalinos de alto-K, metaluminosos, com epidoto magmático, interpretados como representantes de um arco magmático continental (Estágio I, Van Schmus et al. 2011 e referências), que podem estar relacionadas a este período de subducção. Ao mesmo tempo, desenvolve-se uma extensa frente de sedimentação do tipo flysch, na bacia Riacho do Pontal (Formação Mandacaru).

d) 620-575 Ma - Estágio de colisão

Com o fechamento das bacias de margem passiva e oceânicas intervenientes, colisão continental entre os blocos envolvidos ocorreu ao final do Neoproterozoico. Este é o estágio da deformação compressiva brasiliana, colocação das nappes Casa Nova, pico de metamorfismo da faixa e migmatização na Zona Interna. $O$ volumoso magmatismo da Suíte Rajada desenvolve-se, como 
resultado da fusão crustal causada pelo espessamento e empilhamento das nappes sobre a protuberância norte do cráton do São Francisco.

$$
\text { e) } \sim 575-530 \mathrm{Ma}
$$

Após os estágios finais da orogênese colisional, a Província Borborema passou por um estágio final de ajustamento lateral dos blocos, com o desenvolvimento da extensa rede de zonas de cisalhamento de alto ângulo, das quais a Zona de Cisalhamento Pernambuco Oeste faz parte. Como consequência, as unidades da Zona Interna da Faixa Riacho do Pontal foram deslocadas de suas contrapartes na Zona Transversal. Juntamente aos movimentos de escape lateral, vários plútons sin a pós-colisionais foram colocados por toda a Província Borborema, principalmente representados por corpos sieníticos, dos quais a Suíte Serra da Aldeia / Caboclo faz parte.

O modelo tectônico proposto para a evolução geológica da Faixa Riacho do Pontal, que deve ser encarado como uma hipótese de trabalho, envolve um ciclo completo de placas tectônicas no Neoproterozoico. Esse modelo difere da visão de alguns autores, na qual os blocos da Borborema, São Francisco / Congo, Oeste Africano e Amazonas agiram como um bloco continental coerente desde o Paleoproterozoico (Neves 2003, Neves et al. 2009), no Supercontinente Atlântica (Rogers 1996). Dessa forma, este modelo tem implicações diretas para a compreensão da evolução geológica da Província Borborema e dessa porção do Gondwana Ocidental como um todo, tornando-se imperativos testes futuros para a sua eventual consolidação, principalmente através de estudos de cunho geoquímico, geocronológico e isotópico.

\section{CONCLUSÕES}

A Faixa Riacho do Pontal pode ser dividida em três zonas de características geológicas distintas: Interna, Central e Externa, de norte para sul. A Zona Interna caracteriza-se pela presença de rochas intrusivas relacionadas ao ciclo Cariris Velhos ( 1000-960 Ma), ausente nas outras zonas. A Zona Central é composta pelo Complexo Monte Orebe, caracterizado por metabasaltos cujo quimismo é equivalente ao de basaltos de cadeia oceânica, de idade provável em torno de 740 Ma. A Zona Externa é representada por um conjunto de nappes vergentes para sul, que engloba as rochas metassedimentares das formações Barra Bonita e Mandacaru. Enquanto a primeira representa a sedimentação plataformal em uma margem passiva neoproterozóica desenvolvida na margem norte do Cráton do São Francisco, a segunda é provavelmente relacionada ao desenvolvimento de frentes de sedimentação sin-orogênicas durante a Orogênese
Brasiliana, há aproximadamente 630-575 Ma. Intensa atividade magmática granítica a sienítica, sin a pós-colisional, permeia toda a faixa dobrada.

A evolução estrutural da faixa dobrada é representada por um regime compressivo dividido em três fases principais (D1-D2-D3), seguido por um regime transcorrente (D4), ligado à tectônica de escape lateral de massa predominante na Província Borborema ao final do Neoproterozoico e no Cambriano Inferior ( 575-530 Ma).

Um modelo de evolução geodinâmica para a faixa dobrada envolve a colisão entre um bloco da Província Borborema (Zona Interna) e o Cráton do São Francisco (Zona Externa), com a zona de sutura entre os dois blocos sendo representada pela Zona Central. Esse modelo envolve um ciclo completo de placas tectônicas no Neoproterozoico para essa porção da Província Borborema, e portanto tem implicações diretas para a evolução geológica da província e dessa parte do Gondwana Ocidental como um todo.

\section{AGRADECIMENTOS}

À Fundação de Apoio à Pesquisa de Minas Gerais (FAPEMIG) e à Vale pelo apoio logístico e financeiro através do projeto CRA-RDP-00120-10. Ao revisor anônimo e editores de GEONOMOS.

\section{REFERÊNCIAS BIBLIOGRÁFICAS}

Almeida, C.N. \& Lima, E.S. 1996. Evolução termobarométrica de rochas metamórficas da faixa de dobramentos Riacho do Pontal, folha Cruz de Malta, nordeste brasileiro. In: SBG, Congresso Brasileiro de Geologia, 39, Salvador, Anais, p. 2830.

Angelim, L.A.A. 1988. Programa Levantamentos Geológicos Básicos do Brasil-PLGB, carta geológica, carta metalogenética, Escala 1:100000 Folha SC.24-V-A-III, Santa Filomena, Estados de Pernambuco e Piauí. DNPM/CPRM, 146 p.

Angelim, L.A.A. 1997.Programa Levantamentos Geológicos Básicos do Brasil-PLGB, carta geológica, carta metalogenética, Escala 1:250000 Folha SC.24-V-C, Petrolina, Estados da Bahia, Pernambuco e Piauí. CPRM, $120 \mathrm{p}$

Angelim, L.A.A.\& Kosin, M. 2001 (Org.) Folha Aracaju - NW. Nota Explicativa. CPRM - Serviço Geológico do Brasil. Programa Levantamentos Geológicos do Brasil, CD-Rom.

Barbosa, J.S.F. \& Dominguez, J.M.L. 1996. Mapa Geológico do Estado da Bahia, Texto Explicativo. SGM - UFBA, Salvador, $188 \mathrm{p}$.

Bizzi, L.A., Schobbenhaus, C., Gonçalves, J.H., Baars, F.J., Delgado, I.M., Abram, MD., Neto, R.L., Matos, G.M.M., Santos, J.O.S 2007. Mapa Geológico do Brasil, escala 1:2 500 000. MMECPRM.

Brito Neves, B.B. 1975. Regionalização Geotectônica do PréCambriano Nordestino. Instituto de Geociências da Universidade de São Paulo, Tese de Doutoramento, São Paulo, 198 p.

Brito Neves, B.B., Van Schmus, W.R., Santos, E.J., Campos Neto, M.C., Kozuch, M. 1995. O evento Carirís Velhos na Província 
Borborema: intergração de dados, implicações e perspectivas. Revista Brasileira de Geociências 25, 279-296.

Brito Neves, B.B., Santos, E.J., Van Schmus, W.R. 2000. Tectonic history of the Borborema province. In: Tectonic Evolution of South América. Cordani, U.G., Milani, E.J., Thomaz Filho, A., Campos, D.A.(Editors). 31st International Geological Congress, $151-182 \mathrm{p}$.

Brito Neves, B.B., Van Schmus, W.R., Kozuch, M., Santos, E.J. Petronilho, L. 2005.A zona tectônica Teixeira Terra NovaZTTTN-fundamentos da geologia regional e isotópica. Geologia USP, Série Científica, São Paulo, 5, 57-80.

Brito Neves, B.B. \& Pedreira, A. 2008. Diamictitos e "Cap Dolomites" Sturtianos Sobre o Grupo Jacobina - Araras, Norte de Campo Formoso - Bahia. Geol. USP Ser. Cient., São Paulo, v.8, n.2, p. 11-27.

Caxito F.A. 2013. Geotectônica e evolução crustal das faixas Rio Preto e Riacho do Pontal, estados da Bahia, Pernambuco e Piauí. Universidade Federal de Minas Gerais, Instituto de Geociências, Tese de Doutorado, Belo Horizonte, 288 p.

Dantas, E.L., Brito-Neves, B.B., Fuck, R.A. 2010. Looking for the oldest rocks of South America: Paleoarchean orthogneiss of the Sobradinho Block, northernmost foreland of the São Francisco Craton, Petrolina, Pernambuco, Brazil. VII SSAGI South American Symposium on Isotope Geology, Brasília, p. $137-140$

Ferreira, M.A.F., Ferreira, V.P., Sial, A.N. 1994. Estudo petrológico e geoquímico dos plutões sieníticos de Caboclo e Nova Olinda, cinturão de dobramentos Riacho do Pontal, oeste de Pernambuco. In: Congresso Brasileiro de Geologia, 38, Balneário Camboriú, p. 136 - 137.

Ferreira, M.A.F., Ferreira, V.P., Sial, A.N., Cruz, M.J.M. 1998. Geoquímica e petrogênese dos plútons de Caboclo e Nova Olinda, terreno Riacho Pontal, oeste de Pernambuco. In: Congresso Brasileiro de Geologia, 40, Belo Horizonte, Anais, p. 511

Figueirôa, I. \& Silva Filho, M.A. 1990. Programa Levantamento Geológicos Básicos do Brasil. Carta geológica, carta metalogenética, Escala 1:100 000 Folha SC.24-V-C-III, Petrolina, Estados de Pernambuco e Bahia. DNPM/CPRM, 108 p.

Gava, A., Nascimento, D.A., Vidal, J.L.B. et al., 1983. Geologia. in BRASIL DNPM. Projeto RADAMBRASIL. Folha SC-24/25 ARACAJU/RECIFE. Rio de Janeiro, 1983. 826p. il. p. 27 - 376.

Gava, A., Montes, A.S.L., Oliveira, E.P. 1984. Granitos alcalinos no sudeste do Piauí. Caracterização geológica, petrográfica e geoquímica. In: SBG, Congresso Brasileiro de Geologia, 33, Rio de Janeiro, anais, p. 2767-2786.

Gomes, H.A. 1990. Programa Levantamentos Geológicos Básicos do Brasil: carta geológica, carta metalogenética-previsional Escala 1:100.000 (folha SC.24-V-D-I Itamotinga) Estados de Pernambuco e Bahia. Brasília: DNPM/CPRM, 115p.

Gomes, F.E.M. 1990. Relações litoestratigráfico-estruturais e evolução tectônica na Faixa Riacho do Pontal - Região de Paulistana (PI). In: SBG, XXXVI Congresso Brasileiro de Geologia, Natal, vol. 6: 2843-2857.

Gomes, F.E.M. \& Vasconcelos, A.M. 1991 ProgramaLevantamento Geológicos Básicos do Brasil. Carta geológica, carta metalogenética, Escala 1:100 000 Folha SC.24-V-A-II, Paulistana, Estados de Pernambuco e Piauí. DNPM/CPRM, $146 \mathrm{p}$

Gomes, F.E.M. \&Torres, P.F.M. 1994. Associações plutonovulcanossedimentares no extremo sul da Província Borborema. Exemplos, correlações e paradigmas.In: SBG,
Congresso Brasileiro de Geologia, 38, Balneário Camboriú, Anais, p. 47-49.

Jardim de Sá, E.F., Macedo, M.H.F., Torres, H.H.F., Kawashita, K. 1988. Geochronology of metaplutonics and evolution of supracrustal belts in the Borborema Province, NE Brazil. In: Cong. Latino-Americano de Geologia, 7, Belém, Anais, p. 4962.

Jardim de Sá, E.F., Macedo, M.H.F., Fuck, R.A., Kawashita, K. 1992 Terrenos proterozoicos na província Borborema e a margem norte do Cráton do São Francisco. Rev. Brás. Geoc., 22(4), $472-480$

Jardim de Sá, E.F., Macedo, M.H.F., Kawashita, K., Peucat, J.J., Leterrier, J., Fuck, R.A.. 1996. A suíte Serra da Esperança: intrusões alcalinas sintectônicas aos nappes brasilianos na Faixa Riacho do Pontal, NE do Brasil. In: 39 Congresso Brasileiro de Geologia, SBG, Salvador, 6: 499-501.

Kosin, M.D., Angelim, L.A.A., Souza, J.D., Guimarães, J.T., Teixeira, L.R., Martins, A.A.M., Bento, R.V., Santos, R.A., Vasconcelos, A.M., Neves, J.P., Wanderley, A.A., Carvalho, L.M., Pereira, L.H.M., Gomes, I.P. 2004. Folha SC.24-Aracaju. In: Schobbenhaus, C., Gonçalves, J.H., Santos, J.O.S., Abram, M.B., Leão Neto, R., Matos, G.M.M., Vidotti, R.M., Ramos, M.A.B., Jesus, J.D.A. de (eds.). Carta Geológica do Brasil ao Milionésimo, Sistema de Informações Geográficas. Programa Geologia do Brasil. CPRM, Brasília. CD-ROM.

Kreysing, K., Lenz, R., Ribeiro, G.F. 1973. Salinização das águas subterrâneas do centro do polígono das secas do nordeste brasileiro. Recife:SUDENE. 69p. il.

Marimon, M.P.C. 1990. Petrologia e litogeoquímica da seqüência plutono-vulcanosedimentar de Brejo Seco, Município de São João do Piauí. Universidade Federal da Bahia, Curso de PósGraduação, Dissertação de Mestrado, Salvador, 102 pg.

Mendes, V.A. \& Silva Filho, M.A. 1990. Programa Levantamentos Geológicos Básicos do Brasil: carta geológica, carta metalogenética/previsional - Escala 1:100.000 (folha SC.24-VB-IV Cristália), Estado de Pernambuco. Brasília: DNPM/CPRM, 1990. 118p.

Moraes, J.F.S. 1992. Petrologia das rochas máficas-ultramáficas da seqüência vulcanosedimentar de Monte Orebe, PE-PI. Universidade Federal da Bahia, Curso de Pós-Graduação, Dissertação de Mestrado, Salvador, 98 pg.

Moraes, J.F.S., Figuerôa, I. 1998. Programa Levantamentos Geológicos Básicos do Brasil-PLGB, carta geológica, carta metalogenética, Escala 1:250.000 Folha SC.24-V-A, Paulistana, Estados do Piauí, Bahia e Pernambuco. CPRM, 92

Neves, S.P. 2003. Proterozoic history of the Borborema province (NE Brazil): Correlations with neighboring cratons and PanAfrican belts and implications for the evolution of western Gondwana. Tectonics 22,1031,. doi:10.1029/2001TC001352.

Neves, S.P. \& Mariano, G. 1999. Assessing the tectonic significance of a large-scale transcurrent shear zone system: the Pernambuco lineament, northeastern Brazil. Journal of Structural Geology 21, 1369-1383.

Neves, S.P., Bruguier, O.,Silva, J.M.R., Bosch, D., Alcantara, V.C., Lima, C.M. 2009. The age distributions of detrital zircons in metasedimentary sequences in eastern Borborema Province (NE Brazil): evidence for intracontinental sedimentation and orogenesis? Precambrian Research 175, 187-205.

Oliveira, R.G. 1998. Arcabouço geotectônico da região da Faixa Riacho do Pontal, Nordeste do Brasil: dados aeromagnéticos e gravimétricos. Dissertação de Mestrado, IG-USP, 157 p.

Oliveira, R.G. 2008. Arcabouço geofísico, isostasia e causas do magmatismo cenozoico da Província Borborema e sua 
margem continental (nordeste do Brasil). Universidade Federal do Rio Grande do Norte, Tese de Doutorado, Natal, $411 \mathrm{p}$.

Pla Cid, J., Bitencourt, M.F., Nardi, L.V.S., Conceição, H., Bonin, B., Lafon, J.M. 2000a. Paleoproterozoic late-orogenic and anorogenic alkaline granitic magmatism from northeast Brazil. Precambrian Research 104(1-2):47-75.

Pla Cid, J., Nardi, L.V.S., Conceição, H., Bonin, B., Jardim de Sá, E.F. $2000 \mathrm{~b}$. The alkaline sílica-satured ultrapotassic magmatism of the Riacho do Pontal fold belt, NE Brazil. Journal of South American Earth Science, 13 (7):661-683.

Prado, F.S. \& Vasconcelos, A.M. 1991. Programa Levantamentos Geológicos Básicos do Brasil: carta geológica, carta metalogenética-previsional Escala 1:100.000 (folha SC.24-VA-IV Barra do Bonito). Estados do Piauí e Bahia. Brasília: DNPM/CPRM, 160p.

Rogers, J.J.W. 1996. A history of continents in the past three billion years.J. Geology, v. 104, pp. 91-107.

Sampaio, T.Q. \& Vasconcelos, A.M. 1991. Programa Levantamentos Geológicos Básicos do Brasil: carta geológica, carta metalogenético-previsional Escala 1:100.000 (folha SC.24-V-A-V Afrânio). Estados de Pernambuco, Piauí e Bahia. Brasília: DNPM/CPRM, 1991. 144p.

Santos, C.A.\& Silva Filho, M.A. 1990. Programa Levantamentos Geológicos Básicos do Brasil. Riacho do Caboclo. Folha SC.24-
V-A-VI, Estados de Pernambuco e Bahia. Secretaria Nacional de Minas e Metalurgia, Texto e Mapas, $113 p$

Santos, E.J., Van Schmus, W.R., Kozuch, M., Brito Neves, B.B. 2010.The Cariris Velhos tectonic event in northeast Brazil. Journal of SouthAmericanEarthSciences 29, 61-76.

Santos, J.F. 1984. Depósito de Níquel de São João do Piauí, Piauí. In: Schobbenhaus, C. and Coelho, C.E.S. (eds), Principais Depósitos Minerais do Brasil: Brasília-DF, DNPM/CVRD, v. 2, p. 341-345.

Souza, J.D., Fernandes Filho, J.; Guimarães, J.T., Lopes, J.N. 1979 Projeto Colomi. Relatório Final, Geologia da Região do Médio São Francisco, texto e mapas. Escala 1:250 000, DNPM-CPRM, Salvador, $389 p$

Van Schmus, W.R., Brito Neves, B.B., Hackspacher, P., Babinski, M. 1995. $\mathrm{U} / \mathrm{Pb}$ and $\mathrm{Sm} / \mathrm{Nd}$ geochronolgic studies of eastern Borborema Province, northeastern Brazil: initial conclusions. Journal of South American Earth Sciences 8, 267-288.

Van Schmus, W.R., Kozuch, M., Brito Neves, B.B. 2011. Precambrian history of the Zona Transversal of the Borborema Province, NE Brazil: Insights from Sm-Nd and U-Pb geochronology. Journal of South American Earth Sciences 31 : 227-252

Vauchez, A. \& Egydio-Silva, M. 1992. Termination of a continentalscale strike-slip fault in partially melted crust: the West Pernambuco shear zone, northeast Brazil. Geology 20, 10071010. 